\title{
Mercury isotopes as tracers of ecology and metabolism in two sympatric shark species ${ }^{\text {मै }}$
}

\author{
Gaël Le Croizier ${ }^{\mathrm{a},}{ }^{*}$, Anne Lorrain ${ }^{\mathrm{b}}$, Jeroen E. Sonke ${ }^{\mathrm{a}}$, Sébastien Jaquemet ${ }^{\mathrm{c}}$, \\ Gauthier Schaal ${ }^{\mathrm{b}}$, Marina Renedo ${ }^{\mathrm{a}}$, Lucien Besnard ${ }^{\mathrm{b}}$, Yves Cherel ${ }^{\mathrm{d}}$, David Point ${ }^{\mathrm{a}}$ \\ ${ }^{a}$ Géosciences Environnement Toulouse (GET), Observatoire Midi Pyrénées (OMP), UMR 5563 CNRS/IRD/Université Paul Sabatier, 14 avenue Edouard Belin, \\ 31400, Toulouse, France \\ ${ }^{\mathrm{b}}$ Univ Brest, CNRS, IRD, Ifremer, LEMAR, F-29280, Plouzané, France \\ ${ }^{c}$ Laboratoire ENTROPIE, UMR 9220 CNRS/IRD/Université de La Réunion, 15 Avenue René Cassin, BP 92003, 97744, Saint-Denis, La Réunion, France \\ d Centre d'Etudes Biologiques de Chizé (CEBC), UMR 7372 du CNRS-La Rochelle Université, 79360, Villiers-en-Bois, France
}

\section{A R T I C L E I N F O}

\section{Article history:}

Received 27 April 2020

Received in revised form 27 May 2020

Accepted 1 June 2020

Available online 10 June 2020

\begin{abstract}
A B S T R A C T
In coastal ecosystems, top predators are exposed to a wide variety of nutrient and contaminant sources due to the diversity of trophic webs within inshore marine habitats. Mercury contamination could represent an additional threat to shark populations that are declining worldwide. Here we measured total mercury, carbon and nitrogen isotopes, as well as mercury isotopes, in two co-occurring shark species (the bull shark Carcharhinus leucas and the tiger shark Galeocerdo cuvier) and their potential prey from a coastal ecosystem of the western Indian Ocean (La Réunion Island). Our primary goals were to (i) determine the main trophic $\mathrm{Hg}$ sources for sharks and (ii) better characterize their diet composition and foraging habitat. $\mathrm{Hg}$ isotope signatures $\left(\Delta^{199} \mathrm{Hg}\right.$ and $\delta^{202} \mathrm{Hg}$ ) of shark prey suggested that bull sharks were exposed to methylmercury $(\mathrm{MeHg})$ produced in offshore epipelagic waters, while tiger sharks were exposed to offshore mesopelagic MeHg with additional microbial transformation in slope sediments. $\Delta{ }^{199} \mathrm{Hg}$ values efficiently traced the ecology of the two predators, demonstrating that bull sharks targeted coastal prey in shallow waters while tiger sharks were mainly foraging on mesopelagic species in the deeper waters of the island slope. Unexpectedly, we found a positive shift in $\delta^{202} \mathrm{Hg}(>1 \% 0)$ between sharks and their prey, leading to high $\delta^{202} \mathrm{Hg}$ values in the two shark species (e.g. $1.91 \pm 0.52 \%$ in bull sharks). This large shift in $\delta^{202} \mathrm{Hg}$ indicates that sharks may display strong MeHg demethylation abilities, possibly reflecting evolutionary pathways for mitigating their MeHg contamination.
\end{abstract}

() 2020 Elsevier Ltd. All rights reserved.

\section{Introduction}

Mercury $(\mathrm{Hg})$ contamination constitutes a major global environmental concern, resulting in deleterious effects on marine organisms due to exposure to the toxic methylmercury ( $\mathrm{MeHg}$ ) form (Cáceres-Saez et al., 2018; Krey et al., 2015; Scheuhammer et al., 2015). Located at the interface between the atmosphere, lands, rivers and oceans, coastal areas are exposed to a wide variety of $\mathrm{Hg}$ sources and are also used extensively and increasingly for a large number of activities, including resource exploitation or tourism. Within these complex ecosystems, long-lived organisms at the top

\footnotetext{
This paper has been recommended for acceptance by Wen-Xiong Wang.

* Corresponding author.

E-mail address: gael.lecroizier@ird.fr (G. Le Croizier).
}

of food webs usually display the highest $\mathrm{Hg}$ levels, due to bioaccumulation and biomagnification processes, which correspond to the increase of $\mathrm{MeHg}$ and other contaminant concentration over time and with trophic position, respectively. Populations of marine predators are declining worldwide (Baum et al., 2003; Ferretti et al., 2008; Myers and Worm, 2003), including coastal sharks (Hammerschlag et al., 2019; Roff et al., 2018). The harmful effects of $\mathrm{MeHg}$ could thus represent an additional threat to the most depleted shark populations.

The bull shark Carcharhinus leucas and the tiger shark Galeocerdo cuvier are among the largest marine top-predators, playing a key role in tropical marine ecosystems (Roff et al., 2016). Due to their high trophic position and long life span, they are known to accumulate high MeHg levels (McKinney et al., 2016). The two species can be temporarily sympatric (i.e. co-occurring) in coastal ecosystems, but they also exhibit different habitat use involving 
incursions in freshwater and strong affinity for coral reefs for bull sharks (Espinoza et al., 2016; Matich and Heithaus, 2015; Werry et al., 2012) and large offshore movements for tiger sharks (Lea et al., 2015; Meyer et al., 2018), during which they can dive in deep waters (Afonso and Hazin, 2015). Despite similar trophic positions, the two species demonstrate segregation in their feeding habitats. While bull sharks can show high individual specialization and a strong dependence on coastal resources, tiger sharks are generalist predators able to rely on both coastal and oceanic prey (Dicken et al., 2017; Trystram et al., 2016).

Top predators using coastal ecosystems are known to feed on diverse food webs (Bird et al., 2018), inducing exposure to different sources and concentrations of contaminants (Le Croizier et al., 2016, 2019b). To characterize dietary resources, nitrogen and carbon stable isotopes $\left(\delta^{15} \mathrm{~N}\right.$ and $\left.\delta^{13} \mathrm{C}\right)$ are traditionally used in ecotoxicological studies (Le Bourg et al., 2019; Le Croizier et al., 2020), respectively reflecting the trophic position (Pethybridge et al., 2018) and foraging habitat (Bird et al., 2018) of consumers. However, these tools show limitations, such as the variability of $\mathrm{N}$ and $\mathrm{C}$ isotopic fractionation during trophic transfers (Kim et al., 2012; Malpica-Cruz et al., 2012). More recently, new techniques such as $\mathrm{Hg}$ stable isotope analyses have been applied to characterize the sources and transfer routes of this contaminant (Gehrke et al., 2011; Sackett et al., 2017; Senn et al., 2010).

In seawater, $\mathrm{MeHg}$ is subject to mass-independent fractionation ("MIF", generally represented by $\Delta^{199} \mathrm{Hg}$ ) under the influence of solar radiation, which induces a preferential photochemical demethylation of the light and odd-mass isotopes. In the photic zone (i.e. the part of the water column exposed to light), the remaining $\mathrm{MeHg}$ pool available to marine organisms is therefore enriched in the heavy and odd-mass $\mathrm{Hg}$ isotopes. This process creates a $\Delta^{199} \mathrm{Hg}$ gradient from the surface (photic or epipelagic zone, between 0 and $200 \mathrm{~m}$ deep) to depth (twilight or mesopelagic zone, between 200 and $1000 \mathrm{~m}$ deep), with higher $\Delta^{199} \mathrm{Hg}$ values near the surface. This isotopic gradient allows to trace the vertical foraging habitat of marine consumers (Blum et al., 2013; Madigan et al., 2018; Sackett et al., 2017). Moreover, $\Delta^{199} \mathrm{Hg}$ constitutes a trophic tracer of major interest since $\Delta^{199} \mathrm{Hg}$ values are conserved between prey and predators due to the absence of MIF during trophic interactions or metabolic processes (Kwon et al., 2016, 2012; Masbou et al., 2018).

$\mathrm{Hg}$ isotopes are also subject to mass-dependent fractionation ("MDF", generally represented by $\delta^{202} \mathrm{Hg}$ ) that takes place during physico-chemical processes such as photoreduction (Bergquist and Blum, 2007) and volatilization (Zheng et al., 2007), but also during biological processes such as methylation (Janssen et al., 2016) and demethylation (Perrot et al., 2016). $\delta^{202} \mathrm{Hg}$ can be used to assess $\mathrm{Hg}$ metabolism, such as the transformation of MeHg into less toxic inorganic $\mathrm{Hg}(\mathrm{iHg})$ by demethylation in the liver of marine organisms (Bolea-Fernandez et al., 2019). Indeed, the preferential demethylation of light $\mathrm{Hg}$ isotopes induces an increase in $\delta^{202} \mathrm{Hg}$ in the remaining $\mathrm{MeHg}$ pool which is ultimately accumulated in other tissues such as muscle (Perrot et al., 2016). Thereby, significant enrichment of $\delta^{202} \mathrm{Hg}$ is generally found in mammal muscle and human hair relative to trophic $\mathrm{Hg}$ sources, reflecting in vivo demethylation of MeHg (Laffont et al., 2011; Li et al., 2014; Perrot et al., 2012).

In the western Indian Ocean, only few studies have documented $\mathrm{Hg}$ concentrations in coastal species (Le Bourg et al., 2019; Sardenne et al., 2017), with most studies focusing on offshore organisms (Bodin et al., 2017; Kiszka et al., 2015). In addition to trophic position and body length, foraging habitat was found to influence $\mathrm{Hg}$ levels in various shark species sampled across different locations in the southwestern Indian Ocean, including La
Réunion Island (Le Bourg et al., 2019). Indeed, higher Hg concentrations were observed in offshore and deep-sea species compared to coastal species, suggesting different sources of MeHg exposure between sharks feeding in nearshore shallow waters and those feeding in offshore deep waters (Kiszka et al., 2015; Le Bourg et al., 2019). On the other hand, high $\mathrm{Hg}$ concentrations were found in large coastal shark species from the east coast of South-Africa, without apparent influence of foraging depth (McKinney et al., 2016). The role of feeding depth in $\mathrm{MeHg}$ exposure therefore remains to be clarified for predators using nearshore ecosystems in the western Indian Ocean. Moreover, while hepatic demethylation of MeHg is well known in marine mammals (Bolea-Fernandez et al., 2019; Perrot et al., 2016), bony fish do not appear to have such metabolic capacities. Although it has recently been suggested that sharks may have protective mechanisms that mitigate $\mathrm{Hg}$ toxicity (Merly et al., 2019), to date there is no evidence of MeHg demethylation in sharks.

In this context, the present study focused on two sympatric predator species, the bull and the tiger shark, sampled in a coastal ecosystem of the Indian Ocean (La Réunion Island). The two major objectives were to:

1) Use Hg MIF signatures ( $\Delta^{199} \mathrm{Hg}$ values) as tracers of diet and foraging depth, to determine whether different $\mathrm{MeHg}$ sources contribute to $\mathrm{MeHg}$ burdens in the two shark species.

2) Use $\mathrm{Hg}$ MDF signatures ( $\delta^{202} \mathrm{Hg}$ values) as tracers of $\mathrm{Hg}$ metabolism to evaluate $\mathrm{MeHg}$ demethylation abilities in sharks.

\section{Material and methods}

\subsection{Sampling}

The study was carried out in the coastal ecosystem of La Réunion Island, an oceanic island located in the southwestern Indian Ocean. The island is of volcanic origin and its topography is characterized by abrupt slopes inducing close proximity between coastal and offshore ecosystems. This remote island is far from continental masses and therefore far from the main sources of industrial pollution.

Muscle samples from 20 bull sharks Carcharhinus leucas (10 males, 10 females) and 20 tiger sharks Galeocerdo cuvier ( 8 males, 12 females) were collected from individuals caught by local fishermen along the island slope on the west coast of La Réunion Island in 2015 (Fig. 1). To minimize the impact of ontogenetic changes in diet and habitat on $\mathrm{Hg}$ isotope values, most sharks were sub-adults and adults (i.e. $>259 \mathrm{~cm}$ for tiger sharks (Werry et al., 2014) and $>160 \mathrm{~cm}$ for bull sharks (Werry et al., 2011)) (SI Global dataset), and were thus larger than the size at which dietary shifts occur (i.e. 200-230 cm for tiger sharks and $140 \mathrm{~cm}$ for bull sharks) (Habegger et al., 2012; Lowe et al., 1996).

At La Réunion island, teleost fish species dominate the prey consumed by both bull and tiger sharks, based on stomach contents (i.e. respectively $93 \%$ and $78 \%$ in terms of mass percentage) (Trystram et al., 2016). However, the large diversity of prey (i.e. 56 and 148 species for bull and tiger sharks, respectively) (Trystram et al., 2016) makes it very difficult to cover the full prey spectrum of sharks. In this context, we collected muscle samples from fish with known ecology and representative of the different habitats that sharks could use for foraging and through which $\mathrm{Hg}$ exposure could occur (SI Table S3). In a similar coastal ecosystem (Hawaii, USA), terrestrial freshwater inputs to coastal sediments were previously identified as the primary source of tissue $\mathrm{Hg}$ in the giant trevally Caranx ignobilis (Sackett et al., 2017). In the present study, 


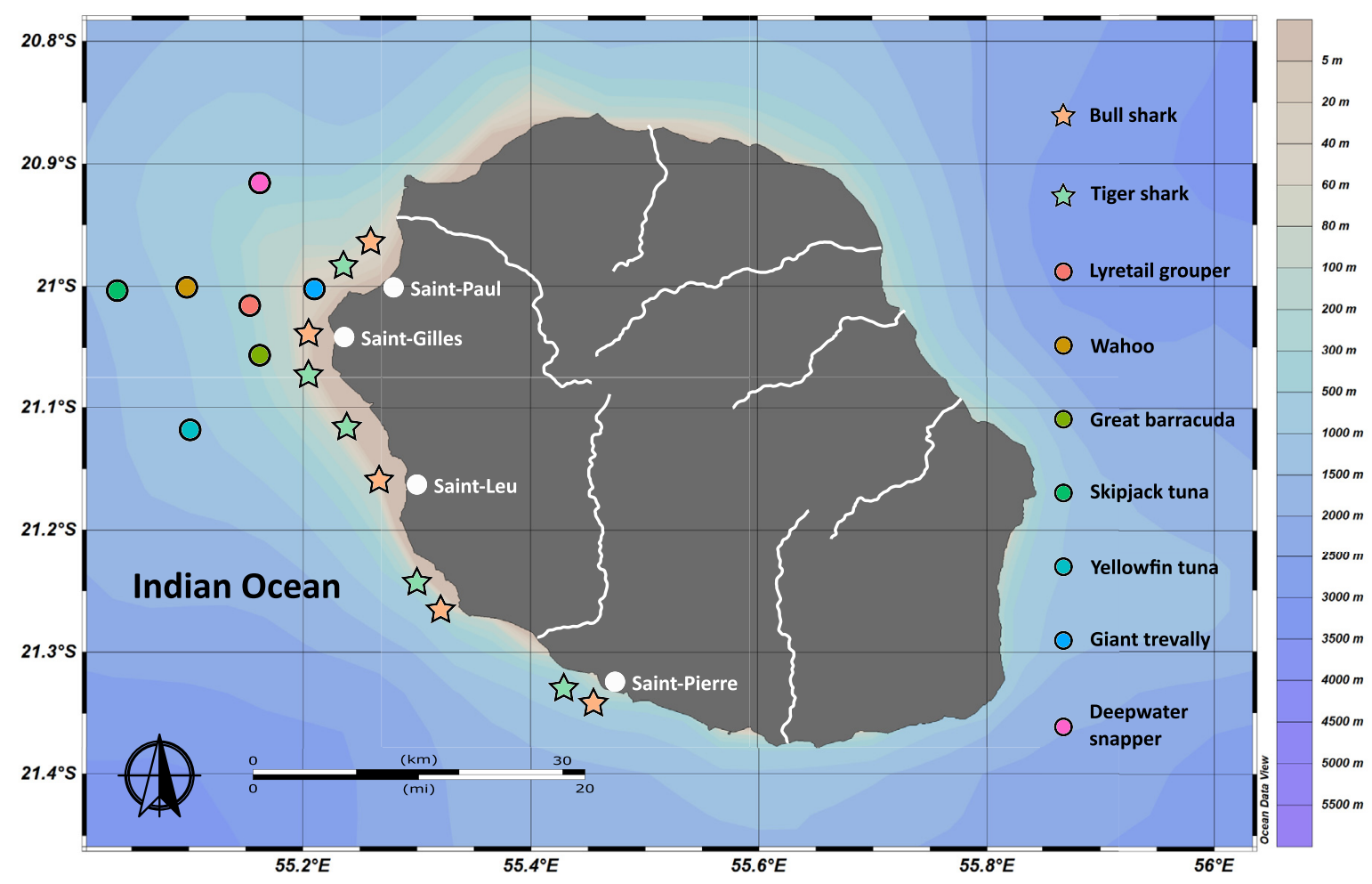

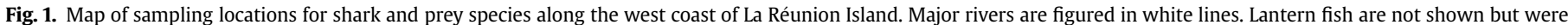
caught in the area (off La Réunion Island and off southern Madagascar).

this fish species was then used as a proxy for $\mathrm{Hg}$ sources from the demersal nearshore habitat. The yellow-edged lyretail Variola louti, a reef-associated grouper was sampled here to represent the shallow coral ecosystem (Emslie et al., 2017) while the great barracuda Sphyraena barracuda and the wahoo Acanthocybium solandri were collected to represent the epipelagic nearshore habitat (Trystram, 2016). The deepwater longtail red snapper Etelis coruscans was identified as primarily exposed to $\mathrm{MeHg}$ through deepwater sediments (Sackett et al., 2017) and was thus used as a proxy for $\mathrm{MeHg}$ sources from slope waters. Regarding pelagic offshore $\mathrm{Hg}$ sources, tuna species (i.e. the yellowfin tuna Thunnus albacares and the skipjack tuna Katsuwonus pelamis) and the lantern fish Ceratoscopelus warmingii were used as proxies for epipelagic and mesopelagic $\mathrm{Hg}$ sources respectively, according to their known ecology and previously published $\mathrm{Hg}$ isotope values (Blum et al., 2013; Madigan et al., 2018). Ceratoscopelus warmingii was collected during the "La Pérouse" and "MAD-RIDGE-1" scientific cruises in 2016 aboard the RV Antea off La Réunion Island and off southern Madagascar, respectively. All other fish species were sampled between January 2012 and December 2014 off the west coast of La Réunion Island by local fishermen (Fig. 1).

All samples were kept in a cool box following collection and thereafter frozen at $-20^{\circ} \mathrm{C}$ in the laboratory until further analysis. Muscle samples were freeze-dried and ground into a fine and homogeneous powder using an automated grinder.

\subsection{Muscle $\delta^{13} \mathrm{C}$ and $\delta^{15} \mathrm{~N}$ values}

Urea and lipid extraction were not applied on shark samples. Although shark muscle generally contains low lipid content $(<1 \%)$ (Meyer et al., 2017), lipids are depleted in ${ }^{13} \mathrm{C}$ and shark osmoregulatory strategy induces a significant retention of urea, which is depleted in ${ }^{15} \mathrm{~N}$. This can bias the interpretation of $\delta^{13} \mathrm{C}$ and $\delta^{15} \mathrm{~N}$ values and a mathematical normalization is therefore commonly applied on these values following urea and lipid extraction (Li et al., 2016b). Here, we applied the normalization equations established for bull and tiger sharks from La Réunion Island, for each species and each sex (Martin and Jaquemet, 2019).

Approximately $0.5 \mathrm{mg}$ of muscle were weighed and packed into tin capsules. Isotopic composition (with a precision of $0.1 \%$ for both $\delta^{13} \mathrm{C}$ and $\delta^{15} \mathrm{~N}$ ) as well as carbon and nitrogen content were measured at the Stable Isotope Laboratory, GNS Science, Lower Hutt, New Zealand, using an Isoprime isotope ratio mass spectrometer interfaced to an EuroEA elemental analyzer in continuous-flow mode (EA-IRMS). Results are expressed in standard $\delta$ notation based on international standards (Vienna Pee Dee Belemnite for $\delta^{13} \mathrm{C}$ and atmospheric nitrogen for $\delta^{15} \mathrm{~N}$ ) following the equation $\delta^{13} \mathrm{C}$ or $\delta^{15} \mathrm{~N}=[($ Rsample/Rstandard $)-1] \times 10^{3}$ (in $\%$ ), where $\mathrm{R}$ is ${ }^{13} \mathrm{C} /{ }^{12} \mathrm{C}$ or ${ }^{15} \mathrm{~N} /{ }^{14} \mathrm{~N}$.

\subsection{Hg concentration and speciation}

Total $\mathrm{Hg}$ ( THg) determination was carried out on an aliquot (around $20 \mathrm{mg}$ ) of dried fish or shark muscle by combustion, gold trapping and atomic absorption spectrophotometry detection using a DMA80 analyzer (Milestone, USA). Mercury concentrations in muscle samples are expressed on a dry weight basis $\left(\mu \mathrm{g} \cdot \mathrm{g}^{-1} \mathrm{dw}\right)$. Only one analysis was performed per sample, but the accuracy and reproducibility of the method were established using two freezedried certified biological materials: a tuna fish flesh homogenate reference material (IAEA 436, IRMM) and a lobster hepatopancreas reference material (TORT 3, NRCC). The certified values for IAEA 436 $\left(4.19 \pm 0.36 \mu \mathrm{g} \mathrm{g}^{-1} \mathrm{dw}\right)$ were reproduced (measured value: $\left.4.20 \pm 0.09 \mu \mathrm{g} \mathrm{g}^{-1} \mathrm{dw}, \mathrm{n}=10\right)$ within the confidence limits. The certified values for TORT $3\left(0.292 \pm 0.022 \mu \mathrm{g} \mathrm{g}^{-1} \mathrm{dw}\right)$ were also reproduced (measured value: $0.286 \pm 0.024 \mu \mathrm{g} \mathrm{g}^{-1} \mathrm{dw}, \mathrm{n}=10$ ) 
within the confidence limits. The detection limit was $0.005 \mu \mathrm{g} \mathrm{g}^{-1}$ dw.

$\mathrm{THg}$ is known to be almost exclusively in the $\mathrm{MeHg}$ form in shark and fish muscle (Bosch et al., 2016; de Carvalho et al., 2014; Pethybridge et al., 2010; Ruiz-de-Cenzano et al., 2014), including species sampled in this study (e.g. giant trevally and deepwater snapper (Sackett et al., 2015), bull shark (Matulik et al., 2017)). However, a subset of muscle samples from 10 bull sharks were analyzed for $\mathrm{MeHg}$, specifically to verify that $\mathrm{MeHg}$ accounted for the majority of THg in our shark muscle samples and to evaluate the link between $\delta^{202} \mathrm{Hg}$ values and $\mathrm{Hg}$ speciation. We focused on the bull shark, which showed the highest $\delta^{202} \mathrm{Hg}$ variability, and selected 5 individuals with the lowest $\delta^{202} \mathrm{Hg}$ values and 5 sharks with the highest $\delta^{202} \mathrm{Hg}$ values (SI Fig. S3). MeHg concentrations in shark samples were obtained by selective and quantitative extraction of MeHg followed by cold-vapor atomic fluorescence spectroscopy (CV-AFS) determination according to the procedure described by (Masbou et al., 2013). MeHg fraction was expressed as the percentage of $\mathrm{MeHg}$ to $\mathrm{THg}$ ratio. A tuna fish flesh homogenate reference material (BCR 464, IRMM) was tested to ensure measurement accuracy and reproducibility, and a $\mathrm{MeHg}$ recovery of $95 \pm 1 \%(\mathrm{n}=2)$ was obtained relative to certified concentration.

\section{4. $\mathrm{Hg}$ isotopes}

Aliquots of approximately $20 \mathrm{mg}$ of dry muscle were left overnight at room temperature in $3 \mathrm{~mL}$ of concentrated bi-distilled nitric acid $\left(\mathrm{HNO}_{3}\right)$. Samples were then digested on a hotplate for $6 \mathrm{~h}$ at $85^{\circ} \mathrm{C}$ in pyrolyzed glass vessels closed by Teflon caps. One $\mathrm{mL}$ of hydrogen peroxide $\left(\mathrm{H}_{2} \mathrm{O}_{2}\right)$ was added and digestion was continued for another $6 \mathrm{~h}$ at $85^{\circ} \mathrm{C}$. One hundred $\mu \mathrm{L}$ of $\mathrm{BrCl}$ was then added to ensure a full oxidation of $\mathrm{MeHg}$ to inorganic $\mathrm{Hg}$. The digested mixtures were finally diluted in an inverse aqua regia ( 3 HNO3: $1 \mathrm{HCl}, 20$ vol\% MilliQ water) to reach a nominal $\mathrm{Hg}$ concentration of $1 \mathrm{ng} \mathrm{g}^{-1}$. Three types of certified reference materials (TORT 3, BCR 464, IAEA 436) and blanks were prepared in the same way as tissue samples (SI Table S1).

Mercury isotope compositions were measured at the Observatoire Midi-Pyrenées using multicollector inductively coupled plasma mass spectrometry (MC-ICP-MS, Thermo Finnigan Neptune Plus) with continuous-flow cold vapor (CV) generation using Sn(II) reduction (CETAC HGX-200), according to a previously published method (Enrico et al., 2016; Goix et al., 2019; Masbou et al., 2015). Hg isotope composition is expressed in $\delta$ notation and reported in permil (\%o) deviation from the NIST SRM 3133 standard, which was determined by sample-standard bracketing according to the following equation: $\delta^{\mathrm{XXX}_{\mathrm{Hg}}} \quad(\% \mathrm{o})=$ [ $\left(\left({ }^{X^{X X}} \mathrm{Hg} /{ }^{198} \mathrm{Hg}\right)_{\text {sample }}\left(\left({ }^{\mathrm{XXX}} \mathrm{Hg} /{ }^{198} \mathrm{Hg}\right)_{\text {NIST } 3133)-1}\right] \mathrm{X} 1000\right.$ where $\mathrm{XXX}$ represents the mass of each mercury isotope. ${ }^{204} \mathrm{Hg}$ was not measured due to limitations in MC-ICP-MS cup configuration. $\delta^{202} \mathrm{Hg}$ is used as a measure of MDF. Measures of MIF are calculated as the difference between a measured $\delta$-value, and the predicted $\delta$ value that is calculated by multiplying the measured $\delta^{202} \mathrm{Hg}$ value by the kinetic MDF fractionation factor for each isotope (Bergquist and Blum, 2007). MIF is expressed by the $\Delta$ notation:

$\Delta^{199} \mathrm{Hg}(\%)=\delta^{199} \mathrm{Hg}-\left(\delta^{202} \mathrm{Hg} \times 0.252\right)$

$\Delta^{200} \mathrm{Hg}(\%)=\delta^{200} \mathrm{Hg}-\left(\delta^{202} \mathrm{Hg} X 0.502\right)$

$\Delta^{201} \mathrm{Hg}(\%)=\delta^{201} \mathrm{Hg}-\left(\delta^{202} \mathrm{Hg} X 0.752\right)$

Total $\mathrm{Hg}$ in the diluted digest mixtures was monitored by MCICP-MS using ${ }^{202} \mathrm{Hg}$ signals: mean recoveries of $95 \pm 6 \%(n=72)$ for samples and $93 \pm 12 \%(n=10)$ for certified reference materials were found, ensuring efficient sample digestion. Hg levels in blanks were below the detection limit. Reproducibility of $\mathrm{Hg}$ isotope measurements was assessed by analyzing UM-Almadén $(n=13)$, ETH-Fluka $(\mathrm{n}=12)$ and the biological tissue procedural standards NRC TORT-3, ERM-BCR-464, and IAEA-436 ( $\mathrm{n}=10)$ (SI Table S1). Only one analysis was performed per sample, but measured isotope signatures as well as analytical reproducibility of standards were found to be in agreement with previously published values (Blum et al., 2013; Jiskra et al., 2017; Li et al., 2016a; Masbou et al., 2013).

\subsection{Statistics}

Data was first checked for normality (Shapiro-Wilks test) and homogeneity of variances (Bartlett test). When these conditions were met, one-way ANOVAs were performed to test for differences between groups, followed by Tukey's HSD tests when more than two groups were compared. Otherwise, non-parametric analogues were used, i.e. Kruskal-Wallis tests (KW), followed by Conover-Iman multiple comparison tests with Bonferroni's adjustment in the presence of several groups.

Depending on data distribution (Shapiro-Wilks test), Pearson or Spearman correlation tests were used to investigate the correlation between shark $\mathrm{THg}$ concentration and other variables (length, mass, $\delta^{15} \mathrm{~N}$ and $\delta^{13} \mathrm{C}$ ).

Using $\delta^{13} \mathrm{C}$ and $\delta^{15} \mathrm{~N}$ values, standard ellipse areas encompassing $95 \%$ of the data $\left(S E A_{B}\right.$, Bayesian SEA) were used to quantify the niche width and overlap between the two shark species, using the "SIBER" package (Jackson et al., 2011). The SEA $A_{B}$ constitutes a proxy for the feeding niche occupied by one species while the overlap between $\mathrm{SEA}_{\mathrm{B}}$ quantifies the trophic competition between species. The $S E A_{B}$ overlap is expressed as a proportion of the nonoverlapping area of the two ellipses.

Linear regressions were used to assess the relationships between i) $\mathrm{Hg}$ metabolism (using $\delta^{202} \mathrm{Hg}$ as a proxy for $\mathrm{MeHg}$ demethylation) and shark age (using length as a proxy for age) (Bolea-Fernandez et al., 2019), ii) $\mathrm{Hg}$ MIF $\left(\Delta^{199} \mathrm{Hg}\right)$ and $\mathrm{Hg}$ MIF $\left(\Delta^{201} \mathrm{Hg}\right)$ as an indicator of $\mathrm{MeHg}$ photodemethylation versus $\mathrm{iHg}$ photoreduction in seawater (Bergquist and Blum, 2007), iii) Hg MIF $\left(\Delta^{199} \mathrm{Hg}\right)$ and $\mathrm{Hg}$ MDF $\left(\delta^{202} \mathrm{Hg}\right)$ as an indicator of $\mathrm{Hg}$ photodegradation versus microbial transformation (Bergquist and Blum, 2007).

Mean values are expressed with one standard deviation (1SD) unless otherwise stated (2SD). All statistical analyses were performed using the open source software R (R Core Team, 2019).

\section{Results}

\subsection{Comparison of the two shark species}

Tiger sharks had higher length (ANOVA; $\mathrm{p}<0.001)$ but similar body mass (KW; p > 0.05) to that of bull sharks (SI Table S2). Bull sharks showed significantly higher $\mathrm{THg}$ concentration $\left(4148 \pm 3069 \mathrm{ng} \mathrm{g}^{-1}\right)(\mathrm{KW} ; \mathrm{p}<0.01)$, as well as higher muscle $\delta^{15} \mathrm{~N}$ $\left(14.22 \pm 0.47 \%\right.$ ) and $\delta^{13} \mathrm{C}$ values $(-16.00 \pm 0.58 \%$ ) (ANOVA; $\mathrm{p}<0.001)$ compared to tiger sharks $\left(3186 \pm 1252 \mathrm{ng} \mathrm{g}^{-1}\right.$, $13.27 \pm 0.54 \%$, $-17.01 \pm 0.49 \%$ or $\mathrm{THg}, \delta^{15} \mathrm{~N}$ and $\delta^{13} \mathrm{C}$ values, respectively) (SI Table S2). THg was positively correlated with total length and body mass for both bull (Pearson; $p<0.001$ ) and tiger sharks (Spearman; $\mathrm{p}<0.05$ ). THg was not correlated with $\delta^{15} \mathrm{~N}$ or $\delta^{13} \mathrm{C}$ values for either species $(\mathrm{p}>0.05)$. The two shark species showed similar carbon and nitrogen isotopic niche area: $5.23 \%{ }^{2}$ for the bull shark and $4.19 \% 0^{2}$ for the tiger shark (SEA $A_{B}$ with $95 \%$ credible interval), and a small area overlap of $18 \%$ (SI Fig. S1). Concerning $\mathrm{Hg}$ isotopes, muscle $\Delta^{199} \mathrm{Hg}$ and $\Delta^{201} \mathrm{Hg}$ values, as well 
as $\delta^{202} \mathrm{Hg}$ values were significantly higher in bull sharks than in tiger sharks $\left(\Delta^{199} \mathrm{Hg}\right.$ and $\Delta^{201} \mathrm{Hg}$ : ANOVA, $\mathrm{p}<0.001 ; \delta^{202} \mathrm{Hg}$ : KW, $\mathrm{p}<0.001$ ) (SI Table S2). No difference was found between species for $\Delta^{200} \mathrm{Hg}(0.08 \%$ and $0.06 \%$ for bull and tiger sharks respectively; ANOVA, $\mathrm{p}>0.05)$. The two sharks showed similar variability in $\Delta{ }^{199} \mathrm{Hg}$ values (Bartlett test, $\mathrm{p}>0.05$ ) (Fig. 2A), whereas bull sharks displayed higher variability for $\delta^{202} \mathrm{Hg}$ values (from 1.04 to $2.82 \%$ )
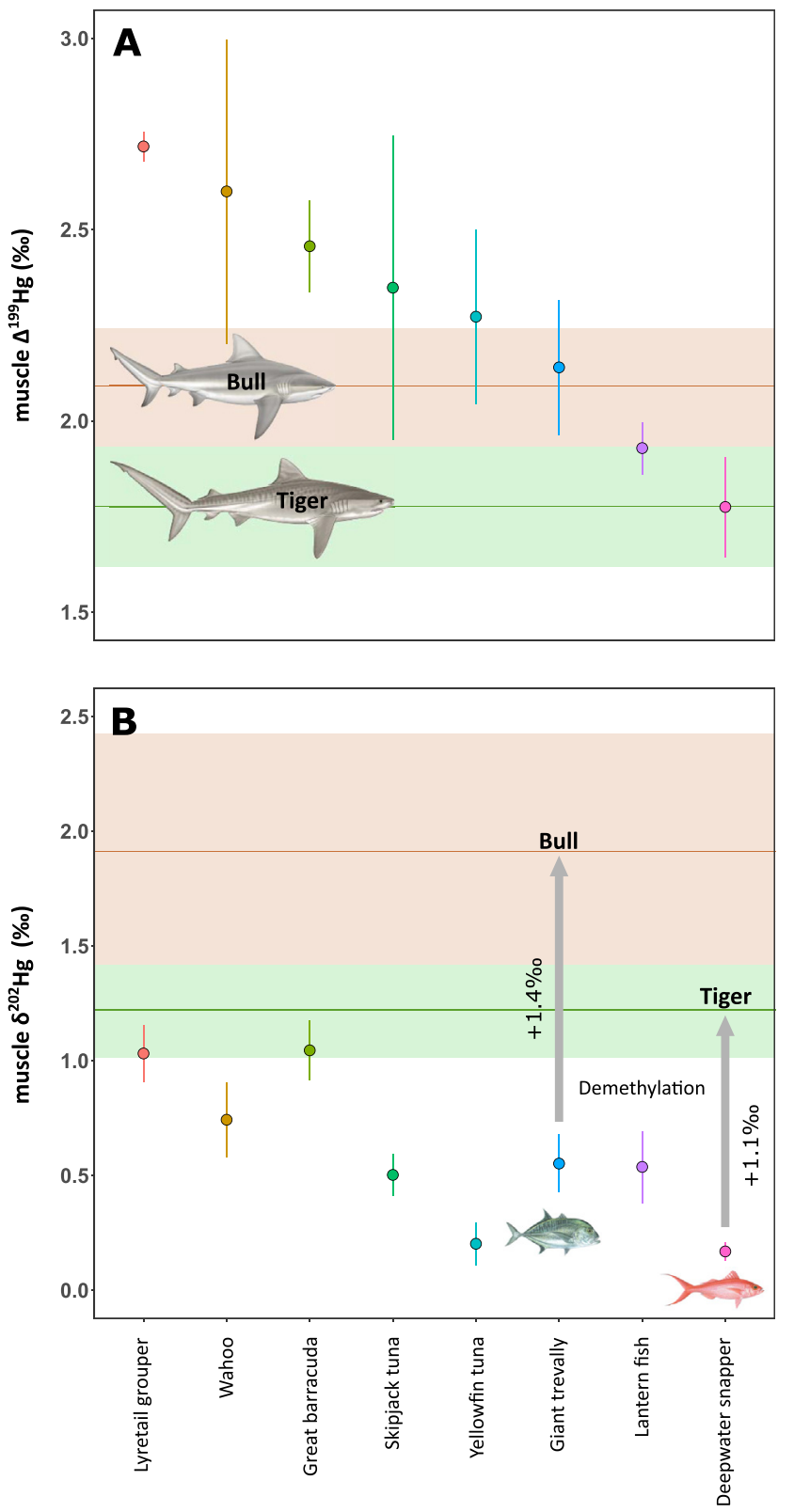

Fig. 2. A: $\Delta^{199} \mathrm{Hg}(\%)$ in bull sharks (orange bar, mean $\pm \mathrm{SD}$ ), tiger sharks (green bar, mean $+\mathrm{SD}$ ) and prey species (dots, mean $+\mathrm{SD}$ ) from La Réunion Island. Prey fish are ordered according to their $\Delta^{199} \mathrm{Hg}$ values. Bull sharks had higher (ANOVA, $\mathrm{p}<0.001$ ) $\Delta{ }^{199} \mathrm{Hg}$ than tiger sharks. The bull shark shared similar $\Delta^{199} \mathrm{Hg}$ with the yellowfin tuna and the giant trevally while the tiger shark shared similar $\Delta^{199} \mathrm{Hg}$ with the deepwater snapper. B: $\delta^{202} \mathrm{Hg}(\%)$ in bull sharks (orange bar, mean $\pm \mathrm{SD}$ ), tiger sharks (green bar, mean $\pm \mathrm{SD}$ ) and prey species (dots, mean $\pm \mathrm{SD})$. Bull sharks had higher $(\mathrm{KW}, \mathrm{p}<0.001)$ and more variable (Bartlett test, $\mathrm{p}<0.001) \delta^{202} \mathrm{Hg}$ values than tiger sharks. The bull shark had higher $\delta^{202} \mathrm{Hg}$ than its prey (e.g. giant trevally; KW, $\mathrm{p}<0.001$ ). Similarly, the tiger shark displayed higher $\delta^{202} \mathrm{Hg}$ than its prey (e.g. deepwater snapper; ANOVA, $p<0.001$ ). (For interpretation of the references to colour in this figure legend, the reader is referred to the Web version of this article.) compared to tiger sharks (from 0.74 to $1.7 \%$ ) (Bartlett test, $\mathrm{p}<0.001$ ) (Fig. 2B). $\Delta^{199} \mathrm{Hg}$ and $\delta^{202} \mathrm{Hg}$ values were not correlated with $\delta^{15} \mathrm{~N}$ or $\delta^{13} \mathrm{C}$ values for either species $(\mathrm{p}>0.05) . \Delta^{199} \mathrm{Hg}$ values were not correlated with body length in the two shark species ( $\mathrm{p}>0.05$ ). A positive correlation was found between length and $\delta^{202} \mathrm{Hg}$ values for the two species $\left(\mathrm{p}<0.001 ; \mathrm{R}^{2}=0.70\right.$ for the bull shark, and $\mathrm{R}^{2}=0.31$ for the tiger shark) (Fig. $3 \mathrm{~A}$ and $\mathrm{B}$ ), and between THg and $\delta^{202} \mathrm{Hg}$ only for the bull shark ( $<<0.001$, SI Fig. S2). $\mathrm{MeHg}$ accounted for $95 \pm 8 \%$ of $\mathrm{THg}$ in bull sharks and the $\mathrm{MeHg}$ fraction was not correlated with length or $\delta^{202} \mathrm{Hg}$ values (SI Fig. S3).

\subsection{Comparison between sharks and prey}

$\Delta^{199} \mathrm{Hg}$ in prey species exhibited a wide range of values, from $1.94 \%$ in the deepwater snapper to $2.72 \%$ in the lyretail grouper (SI Table S3 and Fig. 2A). The bull shark displayed similar $\Delta^{199} \mathrm{Hg}$ as the yellowfin tuna and the giant trevally, while the tiger shark shared similar $\Delta^{199} \mathrm{Hg}$ with the deepwater snapper (ANOVA; $\mathrm{p}>0.05$ ) (Fig. 2A). The two shark species showed different $\Delta^{199} \mathrm{Hg}$ values from all other prey species (i.e. lyretail grouper, wahoo, great barracuda, skipjack tuna, lantern fish) (ANOVA or KW; $\mathrm{p}<0.05$ ). Muscle $\delta^{202} \mathrm{Hg}$ in prey species ranged from $0.20 \%$ in the yellowfin

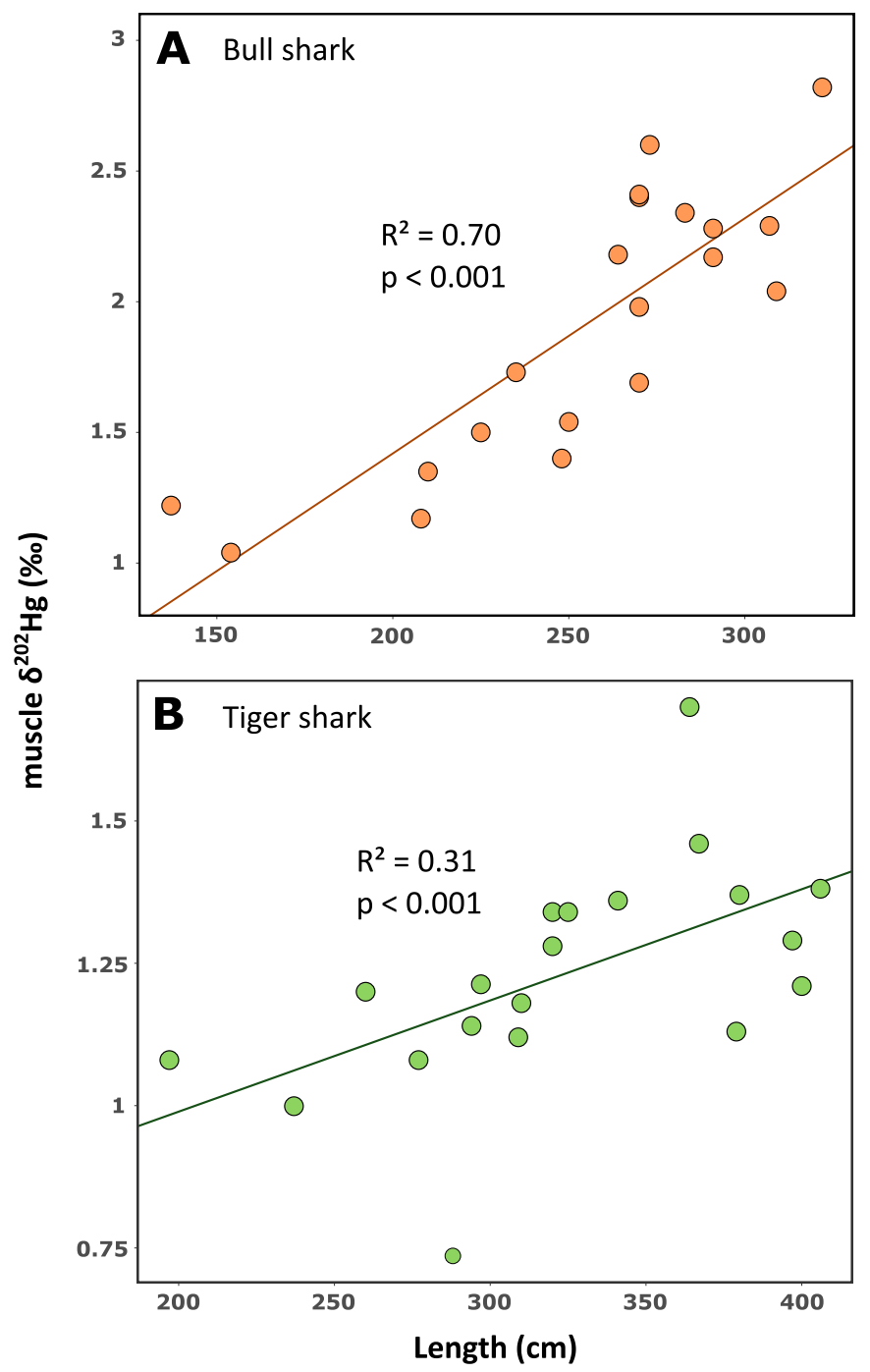

Fig. 3. Muscle $\delta^{202} \mathrm{Hg}$ values versus total length in bull sharks (A) and tiger sharks (B). Data fits a linear regression in $\mathrm{A}$ and $\mathrm{B}$. 
tuna to $1.05 \%$ in the great barracuda (SI Table S3). Bull sharks showed significantly higher $\delta^{202} \mathrm{Hg}$ than all prey species (ANOVA or KW; $\mathrm{p}<0.05$ ) (Fig. 2B). $\delta^{202} \mathrm{Hg}$ in tiger sharks was also higher than in most prey species (ANOVA; $\mathrm{p}<0.001$ ), except for the lyretail grouper and the great barracuda (ANOVA; $\mathrm{p}>0.05$ ).

\section{3. $\mathrm{Hg}$ sources}

The linear regression between $\Delta^{199} \mathrm{Hg}$ and $\Delta^{201} \mathrm{Hg}$ for all fish and shark samples displayed a slope of $1.23 \pm 0.05\left(R^{2}=0.87, p<0.001\right)$ (SI Fig. S4) while the linear regression between $\Delta^{199} \mathrm{Hg}$ and $\delta^{202} \mathrm{Hg}$ for teleost fish only displayed a slope of $0.64 \pm 0.18\left(R^{2}=0.28\right.$, $\mathrm{p}<0.01$ ) (SI Fig. S5). The mesopelagic offshore lantern fish displayed similar $\Delta^{199} \mathrm{Hg}$ and $\delta^{202} \mathrm{Hg}$ values to those of the giant trevally, as well as similar $\Delta^{199} \mathrm{Hg}$ but higher $\delta^{202} \mathrm{Hg}$ than the deepwater snapper (SI Table S3). Compared to the previous study of Sackett et al. (2017) in Hawaii, significantly higher $\delta^{202} \mathrm{Hg}$ was found in the deepwater snapper in the present study (ANOVA, $\mathrm{p}<0.05$ ) (SI Table S4). Despite no significant differences in $\delta^{202} \mathrm{Hg}$ and $\Delta^{199} \mathrm{Hg}$ for the giant trevally between our study and Sackett et al. (2017) (KW, p > 0.05), our values showed lower variance for both $\delta^{202} \mathrm{Hg}$ and $\Delta^{199} \mathrm{Hg}$ (Bartlett test, $\mathrm{p}<0.05$ ).

\section{Discussion}

\section{1. $\mathrm{Hg}$ isotopes as tracers of shark ecology}

\subsection{1. - Foraging depth}

According to the previously documented decrease in $\Delta^{199} \mathrm{Hg}$ values with depth (Blum et al., 2013), the higher $\Delta^{199} \mathrm{Hg}$ values found in bull sharks are likely reflecting the use of shallower waters as main feeding habitat compared to tiger sharks, which would forage in deeper waters (Fig. 2A). In previous studies in coastal environments, estuarine fish were characterized either by higher (Li et al., 2016a) or lower MIF signature (Senn et al., 2010) than open ocean fish, depending on light penetration as a function of water turbidity. Except during episodes of heavy rain, the water clarity in the coastal ecosystem of La Réunion Island implies that $\Delta^{199} \mathrm{Hg}$ values may possibly vary more over a vertical gradient (i.e. depending on depth) than a horizontal gradient (i.e. depending on the distance to the shore). This hypothesis is supported by the fact that epipelagic fish (i.e. living in the upper part of the water column) from the inshore (e.g. wahoo and great barracuda) and offshore habitat (e.g. skipjack and yellowfin tunas) did not differ in $\Delta{ }^{199} \mathrm{Hg}$ values (SI Table S3). Here, $\Delta{ }^{199} \mathrm{Hg}$ values fully corroborate what was previously observed in telemetry studies at this site, showing a higher presence of bull sharks in the coastal environment of La Réunion Island compared to tiger sharks (Blaison et al., 2015). Similarly, bull sharks showed a preferential use of shallow waters in the Indian Ocean when not migrating (usually less than $50 \mathrm{~m}$ with deepest dive at $164 \mathrm{~m}$ ) (Lea et al., 2015), while tiger sharks have been recorded in oceanic waters down to more than $1000 \mathrm{~m}$ (Afonso and Hazin, 2015).

\subsection{2. - Diet composition}

Numerous studies have confirmed that $\Delta^{199} \mathrm{Hg}$ values are conserved between prey and predators due to the absence of photochemical $\mathrm{Hg}$ MIF during trophic interactions or metabolic processes (Kwon et al., 2016, 2012; Masbou et al., 2018), which makes this tool a trophic tracer of major interest. At La Réunion Island, teleost fish species represent the large majority of the prey consumed by both bull and tiger sharks, based on stomach contents (i.e. respectively $93 \%$ and $78 \%$ in terms of mass percentage) (Trystram et al., 2016). Carangid species such as the giant trevally constitute the most consumed family by bull sharks with more than $40 \%$ of the ingested mass, while tiger sharks are more generalist predators and target a large number of teleost families. Stable isotope tracers were in accordance with stomach contents, as the bull shark had similar $\Delta^{199} \mathrm{Hg}$ values (Fig. 2A) but higher $\delta^{15} \mathrm{~N}$ values (as a proxy for trophic position) than the giant trevally $\left(\delta^{15} \mathrm{~N}=14.22 \%\right.$ and $12.53 \%$ for the bull shark and the giant trevally respectively; ANOVA, $\mathrm{p}<0.001$ ), supporting the idea that carangid species are common prey for bull sharks. Alternatively, the largest giant trevallies could also share the feeding habitat of bull sharks, leading to competition for resources and similar $\Delta^{199} \mathrm{Hg}$ values. Associations between these two species have indeed been observed by video and acoustic (Loiseau, unpublished data). On the other hand, taking into account that epipelagic fish from the inshore and offshore habitats did not differ in MIF signatures (SI Table S3), the $\Delta{ }^{199} \mathrm{Hg}$ overlap between the bull shark and yellowfin tuna may only reflect the use of the same water depth across different food webs (i.e. respectively inshore and offshore) rather than trophic interactions, since tuna species were not identified among bull shark prey at La Réunion Island (Trystram et al., 2016). This underlines the importance of considering the information given by stomach contents and trophic positions to interpret $\Delta^{199} \mathrm{Hg}$ values, which are conserved throughout food webs. Here, the tiger shark and the deepwater snapper had similar $\Delta^{199} \mathrm{Hg}$ values (Fig. 2A) but different trophic positions (i.e. higher $\delta^{15} \mathrm{~N}$ for the tiger shark; ANOVA, $\mathrm{p}<0.001)$. As this bottom-associated snapper is found in waters around $300 \mathrm{~m}$ depth (Trystram et al., 2015), it suggests that tiger sharks are primarily targeting prey on the island slope. The two different isotopic approaches used in this study (i.e. $\Delta^{199} \mathrm{Hg}$ and $\delta^{15} \mathrm{~N} / \delta^{13} \mathrm{C}$ ) both lead to the conclusion that the two shark species occupy different trophic niches (different $\Delta^{199} \mathrm{Hg}$ and small SEA overlap) (Figs. 2A and S2) but also that their trophic niches are similar in size (similar variance for $\Delta^{199} \mathrm{Hg}$ (Bartlett Test, $\mathrm{p}>0.05$ ) and similar $\left.S E A_{b}\right)$. In a previous study based on $\delta^{13} \mathrm{C}$ and $\delta^{15} \mathrm{~N}$ values, a trophic independence of the epipelagic fish community (including both bull and tiger sharks) and the mesopelagic fish community was observed (Trystram et al., 2015). Here, Hg isotopes confirm the segregation between bull sharks and deep species such as the deepwater snapper, but in contrast, provide evidence that tiger sharks rely on mesopelagic resources.

Overall, these results highlight the interest of $\mathrm{Hg}$ isotopes to address fundamental ecological questions, such as habitat use and trophic energy transfers (Tsui et al., 2020).

\subsection{Hg isotopes as tracers of shark metabolism}

\subsection{1. - Comparison between sharks and bony fish}

While $\Delta^{199} \mathrm{Hg}$ values in sharks were comparable to those of other fish species in this area (Fig. $2 \mathrm{~A}$ ), $\delta^{202} \mathrm{Hg}$ values were generally higher in sharks compared to their potential teleost prey (Fig. 2B). More precisely, both shark species stood out from their prey by more than $1 \%$ in $\delta^{202} \mathrm{Hg}$ while having similar $\Delta^{199} \mathrm{Hg}$ values. To our knowledge, such high $\delta^{202} \mathrm{Hg}$ values (i.e. $1.9 \%$ in bull sharks and $1.2 \%$ in tiger sharks) have never been reported in fish. However, similar high values have been documented in mammals, including humans, that are able to metabolize $\mathrm{MeHg}$ to inorganic $\mathrm{Hg}$ by demethylation in the liver (Laffont et al., 2011; Masbou et al., 2018, 2015; Perrot et al., 2016). The preferential demethylation of light $\mathrm{Hg}$ isotopes induces an increase in $\delta^{202} \mathrm{Hg}$ in the remaining $\mathrm{MeHg}$ pool that is ultimately accumulated in other tissues such as muscle (Perrot et al., 2016). This increase in $\mathrm{MeHg} \delta^{202} \mathrm{Hg}$ following demethylation varies from about $0.3 \%$ in terrestrial mammals (Ma et al., 2018; Masbou et al., 2018), to around $0.5-1 \%$ in aquatic mammals (Perrot et al., 2016, Li et al., 2020; Perrot et al., 2012) and 
around 2\%o in humans (Laffont et al., 2011, 2009). Previous studies on mercury speciation have concluded that $\mathrm{MeHg}$ demethylation can occur in fish liver and intestine (Gonzalez et al., 2005; Wang et al., 2017). However, experimental studies using $\mathrm{Hg}$ isotopes in fish muscle do not allow to draw clear conclusions, with either no change in MDF signature between $\mathrm{Hg}$ trophic source and consumer (Feng et al., 2015; Kwon et al., 2012), or a positive (+ 0.35\%o) (Kwon et al., 2013) or a negative shift in $\delta^{202} \mathrm{Hg}$ values $(-0.19 \%$ ) (Kwon et al., 2016). In our study, $\delta^{202} \mathrm{Hg}$ values in sharks were well above fractionation values previously published in fish (e.g. $+1.4 \%$ between the bull shark and the giant trevally), with bull sharks having higher $\delta^{202} \mathrm{Hg}$ than all teleost species analyzed. This study represents the first isotopic investigation of $\mathrm{Hg}$ metabolism in sharks and supports the existence of $\mathrm{MeHg}$ demethylation in these predators.

High THg concentrations (around $150 \mu \mathrm{g} \mathrm{L}^{-1}$ ) were found in the blood plasma of South African white sharks Carcharodon carcharias, at levels considered toxic in other vertebrates (Merly et al., 2019). Despite this contamination, no alteration of the body condition nor negative effects on health parameters were observed, suggesting that sharks may have protective mechanisms that mitigate $\mathrm{Hg}$ toxicity. Demethylation in sharks could therefore represent a mechanism limiting the accumulation of $\mathrm{MeHg}$ and its toxic effects. Moreover, MeHg concentrations are generally much higher in muscle compared to other organs such as liver, kidney and brain in shark species (Bergés-Tiznado et al., 2015; Nam et al., 2011), suggesting that muscle could be less sensitive to MeHg toxicity than other tissues in sharks.

\subsection{2. - Hg metabolism versus age}

$\delta^{202} \mathrm{Hg}$ values increased with length, a proxy for age, in the two shark species studied here (Fig. $3 \mathrm{~A}$ and B). Most sharks were subadults and adults, and larger than the size at which ontogenetic changes in habitat and diet occur (Habegger et al., 2012; Lowe et al., 1996). Furthermore, in both shark species, none of the trophic markers analyzed $\left(\delta^{13} \mathrm{C}, \delta^{15} \mathrm{~N}, \Delta{ }^{199} \mathrm{Hg}\right)$ were correlated with size. $\delta^{13} \mathrm{C}$ and $\delta^{15} \mathrm{~N}$ were also not correlated with $\delta^{202} \mathrm{Hg}$, which does not support the influence of ontogenetic diet changes on $\delta^{202} \mathrm{Hg}$ values. On the other hand, an enhancement of the demethylation rate with age was recently identified in the long-finned pilot whale Globicephala melas, leading to the decrease of the $\mathrm{MeHg}$ fraction in the muscle of older whales (from 99\% to 65\%) (Bolea-Fernandez et al., 2019). Since $\mathrm{MeHg}$ has higher $\delta^{202} \mathrm{Hg}$ values compared to inorganic Hg (iHg) (Perrot et al., 2016), the decrease in MeHg fraction alongside the increase in $\mathrm{iHg}$ fraction in pilot whales was accompanied by a drop in $\delta^{202} \mathrm{Hg}$ values (around $1 \%$ decrease) (BoleaFernandez et al., 2019). In our bull shark samples, MeHg accounted for $95 \%$ of total $\mathrm{Hg}$, which is consistent with previous studies on this species (Matulik et al., 2017) or on other sharks (de Carvalho et al., 2014; Nam et al., 2011; Pethybridge et al., 2010). Moreover, no correlation was found between $\mathrm{MeHg}$ fraction and $\delta^{202} \mathrm{Hg}$ or shark length (SI Figs. S3A and S3B). These results imply that the change in $\delta^{202} \mathrm{Hg}$ with age in shark muscle is unlikely to be the result of a variation in $\mathrm{Hg}$ speciation (i.e. $\mathrm{MeHg}$ versus $\mathrm{iHg}$ fraction). We thus hypothesize that the increase in $\delta^{202} \mathrm{Hg}$ values with length could reflect a higher extent of $\mathrm{MeHg}$ demethylation in the liver of older sharks, before preferential storage of the remaining $\mathrm{MeHg}$ over iHg in muscle. By contrast, the aging muscle in pilot whale may gradually favor the storage of $\mathrm{iHg}$ over $\mathrm{MeHg}$ (Bolea-Fernandez et al., 2019). Moreover, a positive correlation was also observed between $\delta^{202} \mathrm{Hg}$ values and $\mathrm{THg}$ (as a proxy for $\mathrm{MeHg}$ ) concentration only in the bull shark muscle (SI Fig. S2). Such a positive correlation between $\delta^{202} \mathrm{Hg}$ and $\mathrm{THg}$ was previously observed in teleost fish species and attributed to the excretion of isotopically light $\mathrm{Hg}$ during $\mathrm{Hg}$ bioaccumulation (Bergquist and Blum, 2007). In the present study, the shift in Hg MDF signature between sharks and their prey (e.g. $+1.4 \%$ for $\delta^{202} \mathrm{Hg}$ between the bull shark and the giant trevally) is well above the values attributed experimentally to excretion in teleost fish (e.g. $+0.35 \%$ o between the amberjack Seriola dumerili compared to its food) (Kwon et al., 2013). However, preferential efflux of $\mathrm{MeHg}$ with light $\mathrm{Hg}$ isotopes over time, through urinary or biliary excretion (Le Croizier et al., 2019a, 2018), may also contribute to the increase in $\delta^{202} \mathrm{Hg}$ values observed in shark muscle. In addition, as previously proposed in pilot whales (Bolea-Fernández et al., 2019), muscle $\mathrm{MeHg}$ may be recycled to the liver and undergo additional demethylation. Thus, older sharks may have experienced more MeHg exchanges between liver and muscle, leading to higher $\delta^{202} \mathrm{Hg}$ values in the remaining $\mathrm{MeHg}$. This hypothesis would explain the increase in $\delta^{202} \mathrm{Hg}$ values with shark length and $\mathrm{THg}$ concentration which both increase with age, respectively due to growth and bioaccumulation.

According to length, the age of individual sharks is supposed to vary from around 5 years to more than 25 years for bull sharks (Natanson et al., 2014) and from around 2 years to more than 15 years for tiger sharks (Meyer et al., 2014). As bull sharks are on average older and display a wider age range, this could explain their higher $\delta^{202} \mathrm{Hg}$ values and higher intraspecific variability compared to tiger sharks (Fig. 2B), caused by an increase in demethylation and/or more liver-muscle exchanges over time.

\subsection{Hg exposure sources to sharks}

\subsection{1. - Hg cycle in the shark environment}

In open oceans, $\mathrm{Hg}$ inputs to surface waters mainly occur through rainfall wet deposition of inorganic $\mathrm{Hg}(\mathrm{iHg})$ and atmospheric dissolution of gaseous $\mathrm{Hg}$ ( $\mathrm{Hg}(0)$ ) (Zhang et al., 2014). Although the processes responsible for the mass-independent fractionation of even $\mathrm{Hg}$ isotopes remain uncertain, $\Delta^{200} \mathrm{Hg}$ is thought to result from high-altitude $\mathrm{Hg}$ photo-oxidation in the tropopause (Chen et al., 2012). iHg wet deposition is characterized by a $\Delta^{200} \mathrm{Hg}$ between 0 and $0.3 \%$ while $\Delta^{200} \mathrm{Hg}$ of atmospheric $\mathrm{Hg}$ (0) ranges from - 0.11 to $-0.01 \%$ (Enrico et al., 2016; Gratz et al., 2010). In the present study, $\Delta^{200} \mathrm{Hg}$ values were similar between the two shark species (i.e. $0.08 \pm 0.04 \%$ in bull sharks and $0.06 \pm 0.04 \%$ in tiger sharks) (SI Table S2), implying that the $\mathrm{iHg}$ precursor to $\mathrm{MeHg}$ in sharks originates from a common source, which may correspond to a combination of rainfall $\mathrm{iHg}$ and gaseous $\mathrm{Hg}(0)$ (with positive and negative $\Delta^{200} \mathrm{Hg}$ values, respectively). Although to our knowledge there is still no data on the isotopic signature of $\mathrm{Hg}(0)$ in this region, preliminary $\Delta^{200} \mathrm{Hg}$ in rainwater collected at La Réunion Island is $0.12 \%$ (Araujo et al., unpublished data), which suggests that $\mathrm{MeHg}$ in sharks is mostly derived from the methylation of $\mathrm{iHg}$ from wet deposition to the marine ecosystem, as previously observed in other aquatic ecosystems (Lepak et al., 2018).

Under the action of solar radiation, dissolved $\mathrm{MeHg}$ will be transformed into $\mathrm{iHg}$ by photodemethylation, while dissolved $\mathrm{iHg}$ will be transformed into $\mathrm{Hg}(0)$ by photoreduction. Photodemethylation of MeHg is characterized by a $\Delta^{199} \mathrm{Hg} / \Delta^{201} \mathrm{Hg}$ ratio of 1.36 while photodegradation of inorganic $\mathrm{Hg}$ leads to a ratio of 1.0 (Bergquist and Blum, 2007). In the present study, overall fish and shark values displayed a $\Delta^{199} \mathrm{Hg} / \Delta^{201} \mathrm{Hg}$ ratio of 1.23 (SI Fig. S4) indicating the dominance of $\mathrm{MeHg}$ demethylation over $\mathrm{iHg}$ photoreduction. This ratio is consistent with those previously reported in coastal and pelagic ecosystems of oceanic islands such as Hawaii (Blum et al., 2013; Sackett et al., 2017).

Experimental studies have shown that $\mathrm{Hg}$ photochemical degradation leads to an approximate $\Delta^{199} \mathrm{Hg} / \delta^{202} \mathrm{Hg}$ slope of 2.4 
whereas microbial transformation (no MIF) is characterized by a slope of 0 (Bergquist and Blum, 2007). In our study, the Hg isotopic signatures of teleost prey displayed a $\Delta^{199} \mathrm{Hg} / \delta^{202} \mathrm{Hg}$ slope of 0.64 (SI Fig. S5), indicating the dominance of microbial transformation (i.e. methylation and/or demethylation) over photochemical degradation, which is similar to previous studies on Hawaiian marine bottomfish (Sackett et al., 2017) and coastal marine fish from the Gulf of Mexico (Senn et al., 2010).

\subsection{2. - Hg isotope signatures in shark prey}

The main trophic MeHg vector for bull sharks at La Réunion Island is thought to be constituted by nearshore fish such as the giant trevally (Trystram et al., 2015), which shared similar $\Delta^{199} \mathrm{Hg}$ and $\delta^{202} \mathrm{Hg}$ with offshore epipelagic species such as the skipjack tuna (SI Table S3, Fig. 4). This result would suggest that MeHg to which bull sharks are exposed via trophic transfer originates from the offshore environment (Fig. 4). This observation contrasts with the findings of a previous study in Hawaii where terrestrial freshwater inputs to coastal sediments were the primary MeHg source for the giant trevally (Sackett et al., 2017), resulting in higher inter- individual variability for both $\Delta^{199} \mathrm{Hg}$ and $\delta^{202} \mathrm{Hg}$ compared to our values (Bartlett test, $\mathrm{p}<0.05$; SI Table S4). This strengthens the hypothesis of limited $\mathrm{MeHg}$ inputs by freshwater runoff of estuarine waters into the coastal ecosystem of La Réunion Island. Rather, $\mathrm{MeHg}$ around La Reunion would originate from the methylation of $\mathrm{iHg}$ that is supplied by rainwater to the marine environment (Fig. 4), as suggested by $\Delta^{200} \mathrm{Hg}$ values.

According to $\Delta^{199} \mathrm{Hg}$ values, mesopelagic species such as the deepwater snapper constitute the main vector of $\mathrm{Hg}$ trophic contamination for tiger sharks (Fig. 2A). The deepwater snapper only shared similar $\Delta^{199} \mathrm{Hg}$ with the lantern fish (SI Table S3, Fig. 4). This is in full agreement with stomach content observations, which revealed that mesopelagic teleosts and especially lantern fish are the main prey of the deepwater snapper, accounting for around $60 \%$ of the total prey abundance (Trystram, 2016). In Hawaii, Hg isotopic signatures of bottom fish including deepwater snappers revealed the incorporation of mesopelagic offshore MeHg sources into slope sediments, where MeHg was subject to additional negative MDF (due to microbial methylation and/or demethylation) before transfer to marine consumers (Sackett et al., 2017). Here, a lower

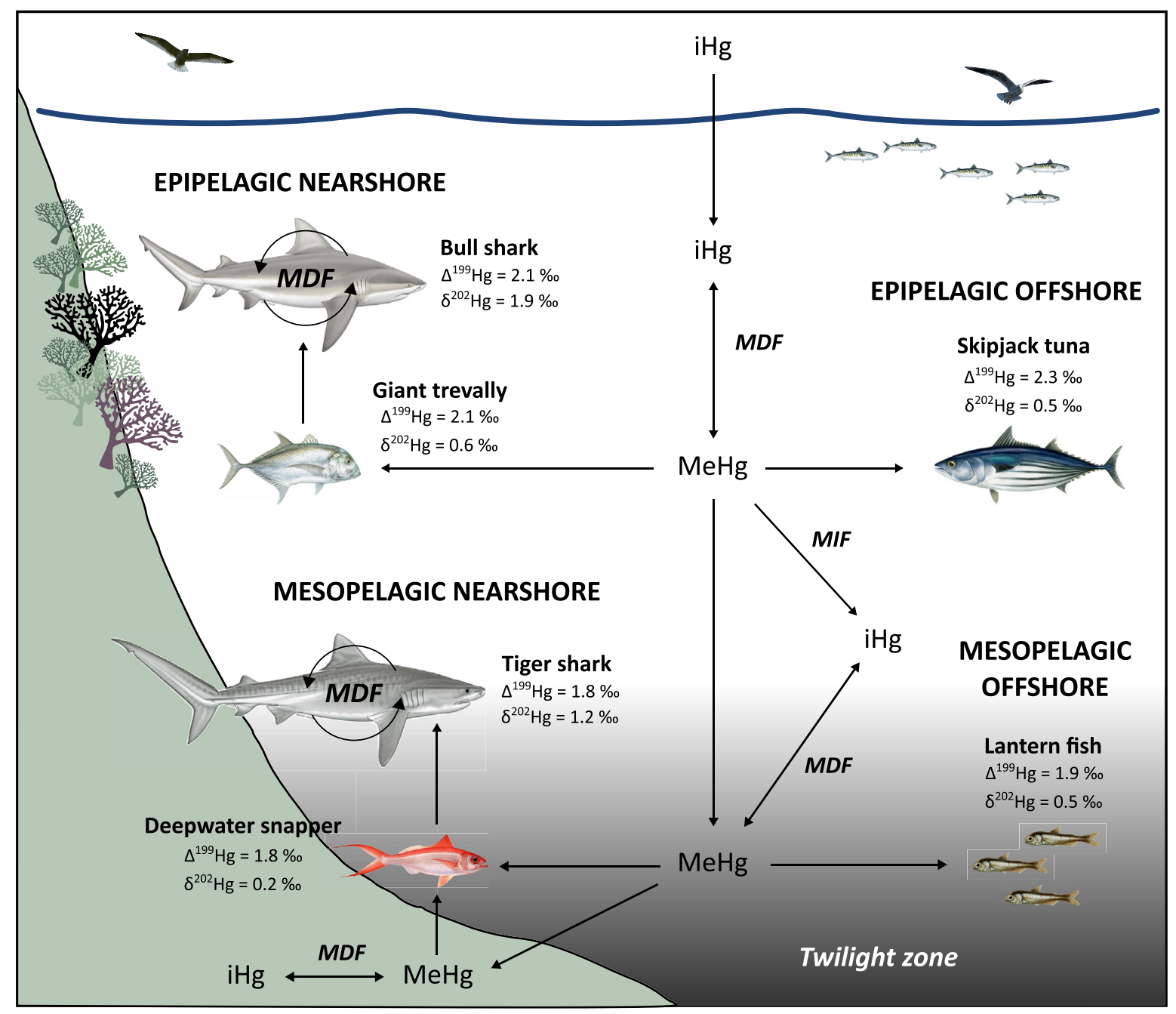

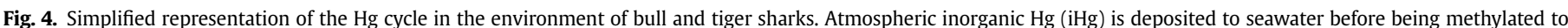

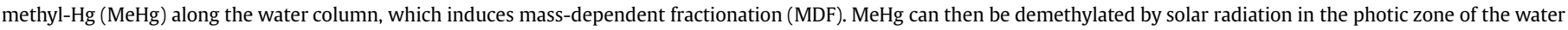

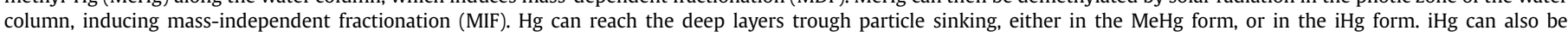

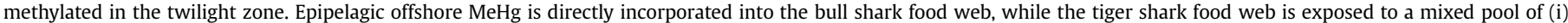

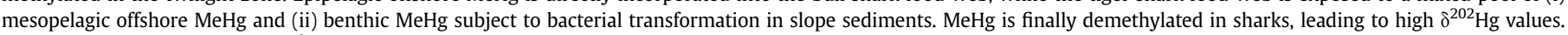
Reduction of $\mathrm{iHg}$ into gaseous $\mathrm{Hg}^{0}$ and subsequent volatilization is not represented. 
$\delta^{202} \mathrm{Hg}$ was similarly found in the deepwater snapper compared to the lantern fish (SI Table S3, Fig. 4). We thus suggest that the decrease in $\delta^{202} \mathrm{Hg}$ between the mesopelagic source and the deepwater snapper is related to its partial consumption of benthic prey (around $20 \%$ of the total prey abundance) (Trystram, 2016) and consequent exposure to a $\mathrm{MeHg}$ pool having undergone microbial MDF (i.e. methylation and/or demethylation) in sediments (Fig. 4). The consumption of benthic prey could also have exposed the deepwater snapper to another source of $\mathrm{MeHg}$ produced in sediments and characterized by a lower $\delta^{202} \mathrm{Hg}$ values than mesopelagic MeHg.

As previously observed for marine fish species in the central Pacific (Blum et al., 2013; Sackett et al., 2017), both bull and tiger sharks were exposed to two different $\mathrm{MeHg}$ pools derived from the same main source of oceanic origin, produced from deposited atmospheric iHg. Bull sharks were exposed to epipelagic offshore $\mathrm{MeHg}$, which was dietary transferred to the epipelagic nearshore habitat (Fig. 4). On the other hand, tiger sharks were exposed to a mixed pool of (i) mesopelagic offshore $\mathrm{MeHg}$ and (ii) benthic $\mathrm{MeHg}$ subject to bacterial transformation in sediments.

\section{Conclusion}

Hg MIF signatures allowed to characterize the vertical feeding habitat of sharks, revealing that bull sharks forage in shallow water while tiger sharks use deeper mesopelagic habitat on the island slope. Our study highlights the potential of $\Delta^{199} \mathrm{Hg}$ values for tracing the ecology of marine species and brings important new perspectives on the habitat use of coastal predators in a context of increasing human-shark interactions. Using $\mathrm{Hg}$ MDF signatures, our results also revealed for the first time the capacity of sharks to breakdown $\mathrm{MeHg}$ via demethylation. This may limit MeHg concentrations in these vulnerable species, among the most contaminated in the animal kingdom.

\section{CRediT authorship contribution statement}

Gaël Le Croizier: Conceptualization, Methodology, Formal analysis, Writing - original draft, Writing - review \& editing. Anne Lorrain: Resources, Writing - review \& editing, Supervision, Funding acquisition. Jeroen E. Sonke: Formal analysis, Resources, Writing - review \& editing, Supervision, Funding acquisition. Sébastien Jaquemet: Investigation, Resources, Writing - review \& editing, Funding acquisition. Gauthier Schaal: Conceptualization, Writing - review \& editing. Marina Renedo: Writing - review \& editing. Lucien Besnard: Writing - review \& editing. Yves Cherel: Resources, Writing - review \& editing. David Point: Resources, Writing - review \& editing, Supervision, Funding acquisition.

\section{Declaration of competing interest}

The authors declare that they have no known competing financial interests or personal relationships that could have appeared to influence the work reported in this paper.

\section{Acknowledgments}

Gaël Le Croizier was supported by a postdoctoral grant from the French National Research Institute for Sustainable Development (IRD). This work was financially supported by the French National Research Agency project ANR-17-CE34-0010 MERTOX. Shark samples were collected as part of the Charc (Feder Fund convention 2011 Presage $N^{\circ} 33021$ ) and Ecoreco-Run (DEAL-Réunion BOP113) projects, fish samples were collected during DIPPLO (FEP, Regional council and TCO funds), ANCRE-DMX2 (FEP fund $\mathrm{N}^{\circ}$ 40055/DMSOI/ 2013), La Pérouse cruise (DOI: 10.17600/16004500) and MADRIDGE-2 cruise (DOI: 10.17600/16004900). C. Trystram contributed to the data collection and laboratory processes at GNS Sciences under the supervision of K. Rogers. We thank Laure Laffont and Jérôme Chmeleff for expert management of the OMP mercury and mass spectrometry facilities. We finally thank Marc Dando for allowing us to use his shark illustrations.

\section{Appendix A. Supplementary data}

Supplementary data to this article can be found online at https://doi.org/10.1016/j.envpol.2020.114931.

\section{References}

Afonso, A.S., Hazin, F.H.V., 2015. Vertical movement patterns and ontogenetic niche expansion in the tiger shark, Galeocerdo cuvier. PloS One 10, e0116720. https:// doi.org/10.1371/journal.pone.0116720.

Baum, J.K., Myers, R.A., Kehler, D.G., Worm, B., Harley, S.J., Doherty, P.A., 2003. Collapse and conservation of shark populations in the northwest atlantic. Science 299, 389-392. https://doi.org/10.1126/science.1079777.

Bergés-Tiznado, M.E., Márquez-Farías, F., Lara-Mendoza, R.E., Torres-Rojas, Y.E., Galván-Magaña, F., Bojórquez-Leyva, H., Páez-Osuna, F., 2015. Mercury and Selenium in Muscle and Target Organs of Scalloped Hammerhead Sharks Sphyrna lewini of the SE Gulf of California: Dietary Intake, Molar Ratios, Loads, and Human Health Risks. Arch Environ Contam Toxicol 69, 440-452. https:// doi.org/10.1007/s00244-015-0226-8.

Bergquist, B.A., Blum, J.D., 2007. Mass-dependent and -independent fractionation of $\mathrm{Hg}$ isotopes by photoreduction in aquatic systems. Science $318,417-420$ https://doi.org/10.1126/science.1148050.

Bird, C.S., Veríssimo, A., Magozzi, S., Abrantes, K.G., Aguilar, A., Al-Reasi, H., Barnett, A., Bethea, D.M., Biais, G., Borrell, A., Bouchoucha, M., Boyle, M., Brooks, E.J., Brunnschweiler, J., Bustamante, P., Carlisle, A., Catarino, D., Caut, S., Cherel, Y., Chouvelon, T., Churchill, D., Ciancio, J., Claes, J., Colaço, A., Courtney, D.L., Cresson, P., Daly, R., Necker, L. de, Endo, T., Figueiredo, I., Frisch, A.J., Hansen, J.H., Heithaus, M., Hussey, N.E., Iitembu, J., Juanes, F., Kinney, M.J., Kiszka, J.J., Klarian, S.A., Kopp, D., Leaf, R., Li, Y., Lorrain, A., Madigan, D.J. Maljković, A. Malpica-Cruz, L., Matich, P., Meekan, M.G. Ménard, F., Menezes, G.M., Munroe, S.E.M., Newman, M.C., Papastamatiou, Y.P., Pethybridge, H., Plumlee, J.D., Polo-Silva, C., Quaeck-Davies, K., Raoult, V., Reum, J., Torres-Rojas, Y.E., Shiffman, D.S., Shipley, O.N., Speed, C.W., Staudinger, M.D., Teffer, A.K., Tilley, A., Valls, M., Vaudo, J.J., Wai, T.-C., Wells, R.J.D., Wyatt, A.S.J., Yool, A., Trueman, C.N., 2018. A global perspective on the trophic geography of sharks. Nat. Ecol. Evol. 2, 299-305. https://doi.org/ 10.1038/s41559-017-0432-z.

Blaison, A., Jaquemet, S., Guyomard, D., Vangrevelynghe, G., Gazzo, T., Cliff, G., Cotel, P., Soria, M., 2015. Seasonal variability of bull and tiger shark presence on the west coast of Reunion Island, western Indian Ocean. Afr. J. Mar. Sci. 37, 199-208. https://doi.org/10.2989/1814232X.2015.1050453.

Blum, J.D., Popp, B.N., Drazen, J.C., Anela Choy, C., Johnson, M.W., 2013. Methylmercury production below the mixed layer in the north pacific ocean. Nat. Geosci. 6, 879-884. https://doi.org/10.1038/ngeo1918.

Bodin, N., Lesperance, D., Albert, R., Hollanda, S., Michaud, P., Degroote, M., Churlaud, C., Bustamante, P., 2017. Trace elements in oceanic pelagic communities in the western Indian Ocean. Chemosphere 174, 354-362. https://doi.org/ 10.1016/j.chemosphere.2017.01.099.

Bolea-Fernández, E., Rua-Ibarz, A., Krupp, E., Feldmann, J., Vanhaecke, F., 2019. Highprecision isotopic analysis sheds new light on mercury metabolism in longfinned pilot whales (Globicephala melas). Sci. Rep. 9 https://doi.org/10.1038/ s41598-019-43825-z.

Bolea-Fernandez, E., Rua-Ibarz, A., Krupp, E.M., Feldmann, J., Vanhaecke, F., 2019. High-precision isotopic analysis sheds new light on mercury metabolism in long-finned pilot whales ( Globicephala melas ). Sci. Rep. 9, 7262. https:// doi.org/10.1038/s41598-019-43825-z.

Bosch, A.C., O’Neill, B., Sigge, G.O., Kerwath, S.E., Hoffman, L.C., 2016. Heavy metal accumulation and toxicity in smoothhound (Mustelus mustelus) shark from Langebaan Lagoon, South Africa. Food Chem. 190, 871-878. https://doi.org/ 10.1016/j.foodchem.2015.06.034.

Cáceres-Saez, I., Haro, D., Blank, O., Aguayo Lobo, A., Dougnac, C., Arredondo, C., Cappozzo, H.L., Guevara, S.R., 2018. High status of mercury and selenium in false killer whales (Pseudorca crassidens, Owen 1846) stranded on Southern South America: a possible toxicological concern? Chemosphere 199, 637-646. https:// doi.org/10.1016/j.chemosphere.2018.02.046.

Chen, J., Hintelmann, H., Feng, X., Dimock, B., 2012. Unusual fractionation of both odd and even mercury isotopes in precipitation from Peterborough, ON, Canada. Geochem. Cosmochim. Acta 90, 33-46. https://doi.org/10.1016/ j.gca.2012.05.005.

de Carvalho, G.G.A., Degaspari, I.A.M., Branco, V., Canário, J., de Amorim, A.F., Kennedy, V.H., Ferreira, J.R., 2014. Assessment of total and organic mercury 
levels in blue sharks (Prionace glauca) from the south and southeastern Brazilian coast. Biol. Trace Elem. Res. 159, 128-134. https://doi.org/10.1007/s12011014-9995-6.

Dicken, M.L., Hussey, N.E., Christiansen, H.M., Smale, M.J., Nkabi, N., Cliff, G., Wintner, S.P., 2017. Diet and trophic ecology of the tiger shark (Galeocerdo cuvier) from South African waters. PloS One 12, e0177897. https://doi.org/ 10.1371/journal.pone.0177897.

Emslie, M.J., Cheal, A.J., Logan, M., 2017. The distribution and abundance of reefassociated predatory fishes on the Great Barrier Reef. Coral Reefs 36, 829-846. https://doi.org/10.1007/s00338-017-1573-x.

Enrico, M., Roux, G.L., Marusczak, N., Heimbürger, L.-E., Claustres, A., Fu, X., Sun, R., Sonke, J.E., 2016. Atmospheric mercury transfer to peat bogs dominated by gaseous elemental mercury dry deposition. Environ. Sci. Technol. 50, 2405-2412. https://doi.org/10.1021/acs.est.5b06058.

Espinoza, M., Heupel, M.R., Tobin, A.J., Simpfendorfer, C.A., 2016. Evidence of partial migration in a large coastal predator: opportunistic foraging and reproduction as key drivers? PloS One 11, e0147608. https://doi.org/10.1371/ journal.pone.0147608.

Feng, C., Pedrero, Z., Gentès, S., Barre, J., Renedo, M., Tessier, E., Berail, S., MauryBrachet, R., Mesmer-Dudons, N., Baudrimont, M., Legeay, A., Maurice, L., Gonzalez, P., Amouroux, D., 2015. Specific pathways of dietary methylmercury and inorganic mercury determined by mercury speciation and isotopic composition in zebrafish (Danio rerio). Environ. Sci. Technol. 49, 12984-12993. https://doi.org/10.1021/acs.est.5b03587.

Ferretti, F., Myers, R.A., Serena, F., Lotze, H.K., 2008. Loss of large predatory sharks from the mediterranean sea. Conserv. Biol. 22, 952-964. https://doi.org 10.1111/j.1523-1739.2008.00938.x.

Gehrke, G.E., Blum, J.D., Slotton, D.G., Greenfield, B.K., 2011. Mercury isotopes link mercury in san francisco bay forage fish to surface sediments. Environ. Sci. Technol. 45, 1264-1270. https://doi.org/10.1021/es103053y.

Goix, S., Maurice, L., Laffont, L., Rinaldo, R., Lagane, C., Chmeleff, J., Menges, J., Heimbürger, L.-E., Maury-Brachet, R., Sonke, J.E., 2019. Quantifying the impacts of artisanal gold mining on a tropical river system using mercury isotopes. Chemosphere 219, 684-694. https://doi.org/10.1016/ j.chemosphere.2018.12.036.

Gonzalez, P., Dominique, Y., Massabuau, J.C., Boudou, A., Bourdineaud, J.P., 2005. Comparative effects of dietary methylmercury on gene expression in liver skeletal muscle, and brain of the zebrafish (Danio rerio). Environ. Sci. Technol. 39, 3972-3980. https://doi.org/10.1021/es0483490.

Gratz, L.E., Keeler, G.J., Blum, J.D., Sherman, L.S., 2010. Isotopic composition and fractionation of mercury in great lakes precipitation and ambient air. Environ. Sci. Technol. 44, 7764-7770. https://doi.org/10.1021/es100383w.

Habegger, M.L., Motta, P.J., Huber, D.R., Dean, M.N., 2012. Feeding biomechanics and theoretical calculations of bite force in bull sharks (Carcharhinus leucas) during ontogeny. Zoology 115, 354-364. https://doi.org/10.1016/j.zool.2012.04.007.

Hammerschlag, N., Williams, L., Fallows, M., Fallows, C., 2019. Disappearance of white sharks leads to the novel emergence of an allopatric apex predator, the sevengill shark. Sci. Rep. 9, 1908. https://doi.org/10.1038/s41598-018-37576-6.

Jackson, A.L., Inger, R., Parnell, A.C., Bearhop, S., 2011. Comparing isotopic niche widths among and within communities: SIBER - stable Isotope Bayesian Ellipses in R. J. Anim. Ecol. 80, 595-602. https://doi.org/10.1111/j.13652656.2011.01806.x.

Janssen, S.E., Schaefer, J.K., Barkay, T., Reinfelder, J.R., 2016. Fractionation of mercury stable isotopes during microbial methylmercury production by iron- and sulfate-reducing bacteria. Environ. Sci. Technol. 50, 8077-8083. https://doi.org/ 10.1021 /acs.est.6b00854.

Jiskra, M.G., Wiederhold, J., Skyllberg, U., Kronberg, R.-M., Kretzschmar, R., 2017. Source tracing of natural organic matter bound mercury in boreal forest runoff with mercury stable isotopes. Environ. Sci.: Processes \& Impacts 19, 1235-1248. https://doi.org/10.1039/C7EM00245A.

Kim, S.L., del Rio, C.M., Casper, D., Koch, P.L., 2012. Isotopic incorporation rates for shark tissues from a long-term captive feeding study. J. Exp. Biol. 215, 2495-2500. https://doi.org/10.1242/jeb.070656.

Kiszka, J.J., Aubail, A., Hussey, N.E., Heithaus, M.R., Caurant, F., Bustamante, P., 2015. Plasticity of trophic interactions among sharks from the oceanic south-western Indian Ocean revealed by stable isotope and mercury analyses. Deep Sea Res. Oceanogr. Res. Pap. 96, 49-58. https://doi.org/10.1016/j.dsr.2014.11.006.

Krey, A., Ostertag, S.K., Chan, H.M., 2015. Assessment of neurotoxic effects of mercury in beluga whales (Delphinapterus leucas), ringed seals (Pusa hispida), and polar bears (Ursus maritimus) from the Canadian Arctic. Sci. Environ. Special Issue: Mercury in Canada's North 509-510, 237-247. https://doi.org/10.1016/ j.scitotenv.2014.05.134.

Kwon, S.Y., Blum, J.D., Carvan, M.J., Basu, N., Head, J.A., Madenjian, C.P., David, S.R., 2012. Absence of fractionation of mercury isotopes during trophic transfer of methylmercury to freshwater fish in captivity. Environ. Sci. Technol. 46, 7527. https://doi.org/10.1021/es300794q.

Kwon, S.Y., Blum, J.D., Chirby, M.A., Chesney, E.J., 2013. Application of mercury isotopes for tracing trophic transfer and internal distribution of mercury in marine fish feeding experiments. Environ. Toxicol. Chem. 32, 2322-2330. https://doi.org/10.1002/etc.2313.

Kwon, S.Y., Blum, J.D., Madigan, D.J., Block, B.A., Popp, B.N., 2016. Quantifying mercury isotope dynamics in captive Pacific bluefin tuna (Thunnus orientalis) Elem. Sci. Anth 4. https://doi.org/10.12952/journal.elementa.000088.

Laffont, L., Sonke, J.E., Maurice, L., Hintelmann, H., Pouilly, M., Sánchez Bacarreza, Y., Perez, T., Behra, P., 2009. Anomalous mercury isotopic compositions of fish and human hair in the Bolivian amazon. Environ. Sci. Technol. 43, 8985-8990. https://doi.org/10.1021/es9019518.

Laffont, L., Sonke, J.E., Maurice, L., Monrroy, S.L., Chincheros, J., Amouroux, D. Behra, P., 2011. Hg speciation and stable isotope signatures in human hair as a tracer for dietary and occupational exposure to mercury. Environ. Sci. Technol. 45, 9910-9916. https://doi.org/10.1021/es202353m.

Le Bourg, B., Kiszka, J.J., Bustamante, P., Heithaus, M.R., Jaquemet, S., Humber, F., 2019. Effect of body length, trophic position and habitat use on mercury concentrations of sharks from contrasted ecosystems in the southwestern Indian Ocean. Environ. Res. 169, 387-395. https://doi.org/10.1016/j.envres.2018.11.024.

Le Croizier, G., Lacroix, C., Artigaud, S., Le Floch, S., Munaron, J.-M., Raffray, J., Penicaud, V., Rouget, M.-L., Laë, R., Tito De Morais, L., 2019a. Metal subcellular partitioning determines excretion pathways and sensitivity to cadmium toxicity in two marine fish species. Chemosphere 217, 754-762. https://doi.org/10.1016/ j.chemosphere.2018.10.212.

Le Croizier, G., Lacroix, C., Artigaud, S., Le Floch, S., Raffray, J., Penicaud, V., Coquillé, V., Autier, J., Rouget, M.-L., Le Bayon, N., Laë, R., Tito De Morais, L., 2018. Significance of metallothioneins in differential cadmium accumulation kinetics between two marine fish species. Environ. Pollut. 236, 462-476. https:// doi.org/10.1016/j.envpol.2018.01.002.

Le Croizier, G., Lorrain, A., Schaal, G., Ketchum, J., Hoyos-Padilla, M., Besnard, L. Jean-Marie-Munaron, Le Loc'h, F., Point, D., 2020. Trophic resources and mercury exposure of two silvertip shark populations in the northeast Pacific Ocean. Chemosphere 126645. https://doi.org/10.1016/j.chemosphere.2020.126645.

Le Croizier, G., Schaal, G., Gallon, R., Fall, M., Le Grand, F., Munaron, J.-M., Rouget, M.L., Machu, E., Le Loc'h, F., Laë, R., De Morais, L.T., 2016. Trophic ecology influence on metal bioaccumulation in marine fish: inference from stable isotope and fatty acid analyses. Sci. Total Environ. 573, 83-95. https://doi.org/10.1016/ j.scitotenv.2016.08.035.

Le Croizier, G., Schaal, G., Point, D., Le Loc'h, F., Machu, E., Fall, M., Munaron, J.-M. Boyé, A., Walter, P., Laë, R., Tito De Morais, L., 2019b. Stable isotope analyses revealed the influence of foraging habitat on mercury accumulation in tropical coastal marine fish. Sci. Total Environ. 650, 2129-2140. https://doi.org/10.1016/ j.scitotenv.2018.09.330.

Lea, J.S.E., Humphries, N.E., Clarke, C.R., Sims, D.W., 2015. To Madagascar and back: long-distance, return migration across open ocean by a pregnant female bull shark Carcharhinus leucas. J. Fish. Biol. 87, 1313-1321. https://doi.org/10.1111/ jfb. 12805 .

Lea, J.S.E., Wetherbee, B.M., Queiroz, N., Burnie, N., Aming, C., Sousa, L.L., Mucientes, G.R., Humphries, N.E., Harvey, G.M., Sims, D.W., Shivji, M.S., 2015 Repeated, long-distance migrations by a philopatric predator targeting highly contrasting ecosystems. Sci. Rep. 5, 11202. https://doi.org/10.1038/srep11202.

Lepak, R.F., Janssen, S.E., Yin, R., Krabbenhoft, D.P., Ogorek, J.M., DeWild, J.F., Tate, M.T., Holsen, T.M., Hurley, J.P., 2018. Factors affecting mercury stable isotopic distribution in piscivorous fish of the laurentian great lakes. Environ. Sci. Technol. 52, 2768-2776. https://doi.org/10.1021/acs.est.7b06120.

Li, M., Juang, C.A., Ewald, J.D., Yin, R., Mikkelsen, B., Krabbenhoft, D.P., Balcom, P.H., Dassuncao, C., Sunderland, E.M., 2020. Selenium and stable mercury isotopes provide new insights into mercury toxicokinetics in pilot whales. Sci. Tot. Environ. 710, 136325 https://doi.org/10.1016/j.scitotenv.2019.136325.

Li, M., Schartup, A.T., Valberg, A.P., Ewald, J.D., Krabbenhoft, D.P., Yin, R. Balcom, P.H., Sunderland, E.M., 2016a. Environmental origins of methylmercury accumulated in subarctic estuarine fish indicated by mercury stable isotopes. Environ. Sci. Technol. 50, 11559-11568. https://doi.org/10.1021/acs.est.6b03206.

Li, M., Sherman, L.S., Blum, J.D., Grandjean, P., Mikkelsen, B., Weihe, P. Sunderland, E.M., Shine, J.P., 2014. Assessing sources of human methylmercury exposure using stable mercury isotopes. Environ. Sci. Technol. 48, 8800-8806. https://doi.org/10.1021/es500340r.

Li, Y., Zhang, Y., Hussey, N.E., Dai, X., 2016b. Urea and lipid extraction treatment effects on $\delta 15 \mathrm{~N}$ and $\delta 13 \mathrm{C}$ values in pelagic sharks. Rapid Commun. Mass Spectrom. 30, 1-8. https://doi.org/10.1002/rcm.7396.

Lowe, C.G., Wetherbee, B.M., Crow, G.L., Tester, A.L., 1996. Ontogenetic dietary shifts and feeding behavior of the tiger shark, Galeocerdo cuvier, in Hawaiian waters. Environ. Biol. Fish. 47, 203-211. https://doi.org/10.1007/BF00005044.

Ma, L., Evans, R.D., Wang, W., Georg, R.B., 2018. In vivo fractionation of mercury isotopes in tissues of a mammalian carnivore (Neovison vison). Sci. Total Environ. 627, 1228-1233. https://doi.org/10.1016/j.scitotenv.2018.01.296.

Madigan, D.J., Li, M., Yin, R., Baumann, H., Snodgrass, O.E., Dewar, H. Krabbenhoft, D.P., Baumann, Z., Fisher, N.S., Balcom, P., Sunderland, E.M., 2018. Mercury stable isotopes reveal influence of foraging depth on mercury concentrations and growth in pacific bluefin tuna. Environ. Sci. Technol. 52, 6256-6264. https://doi.org/10.1021/acs.est.7b06429.

Malpica-Cruz, L., Herzka, S.Z., Sosa-Nishizaki, O., Lazo, J.P., 2012. Tissue-specific isotope trophic discrimination factors and turnover rates in a marine elasmobranch: empirical and modeling results. Can. J. Fish. Aquat. Sci. 69, 551-564 https://doi.org/10.1139/f2011-172.

Martin, U.M., Jaquemet, S., 2019. Effects of urea and lipid removal from Carcharhinus leucas and Galeocerdo cuvier white muscle on carbon and nitrogen stable isotope ratios. West. Indian Ocean J. Mar. Sci. 18, 47, 56-56.

Masbou, J., Point, D., Sonke, J.E., 2013. Application of a selective extraction method for methylmercury compound specific stable isotope analysis (MeHg-CSIA) in biological materials. J. Anal. At. Spectrom. 28, 1620-1628. https://doi.org 10.1039/C3JA50185J.

Masbou, J., Point, D., Sonke, J.E., Frappart, F., Perrot, V., Amouroux, D., Richard, P., Becker, P.R., 2015. Hg stable isotope time trend in ringed seals registers 
decreasing sea ice cover in the alaskan arctic. Environ. Sci. Technol. 49, 8977-8985. https://doi.org/10.1021/es5048446.

Masbou, J., Sonke, J.E., Amouroux, D., Guillou, G., Becker, P.R., Point, D., 2018. Hgstable isotope variations in marine top predators of the western arctic ocean ACS Earth Space Chem. https://doi.org/10.1021/acsearthspacechem.8b00017.

Matich, P., Heithaus, M.R., 2015. Individual variation in ontogenetic niche shifts in habitat use and movement patterns of a large estuarine predator (Carcharhinus leucas). Oecologia 178, 347-359. https://doi.org/10.1007/s00442-015-3253-2.

Matulik, A.G., Kerstetter, D.W., Hammerschlag, N., Divoll, T., Hammerschmidt, C.R., Evers, D.C., 2017. Bioaccumulation and biomagnification of mercury and methylmercury in four sympatric coastal sharks in a protected subtropical lagoon. Mar. Pollut. Bull. 116, 357-364. https://doi.org/10.1016/ j.marpolbul.2017.01.033.

McKinney, M.A., Dean, K., Hussey, N.E., Cliff, G., Wintner, S.P., Dudley, S.F.J., Zungu, M.P., Fisk, A.T., 2016. Global versus local causes and health implication of high mercury concentrations in sharks from the east coast of South Africa. Sci. Total Environ. 541, 176-183. https://doi.org/10.1016/j.scitotenv.2015.09.074.

Merly, L., Lange, L., Meÿer, M., Hewitt, A.M., Koen, P., Fischer, C., Muller, J. Schilack, V., Wentzel, M., Hammerschlag, N., 2019. Blood plasma levels of heavy metals and trace elements in white sharks (Carcharodon carcharias) and potential health consequences. Mar. Pollut. Bull. 142, 85-92. https://doi.org/ 10.1016/j.marpolbul.2019.03.018.

Meyer, C.G., Anderson, J.M., Coffey, D.M., Hutchinson, M.R., Royer, M.A., Holland, K.N., 2018. Habitat geography around Hawaii's oceanic islands influences tiger shark ( Galeocerdo cuvier ) spatial behaviour and shark bite risk at ocean recreation sites. Sci. Rep. 8, 4945. https://doi.org/10.1038/s41598-018 23006-0.

Meyer, C.G., O’Malley, J.M., Papastamatiou, Y.P., Dale, J.J., Hutchinson, M.R., Anderson, J.M., Royer, M.A., Holland, K.N., 2014. Growth and maximum size of tiger sharks (Galeocerdo cuvier) in Hawaii. PloS One 9, e84799. https://doi.org 10.1371/journal.pone.0084799.

Meyer, L., Pethybridge, H., Nichols, P.D., Beckmann, C., Bruce, B.D., Werry, J.M., Huveneers, C., 2017. Assessing the functional limitations of lipids and fatty acids for diet determination: the importance of tissue type, quantity, and quality. Front. Mar. Sci. 4 https://doi.org/10.3389/fmars.2017.00369.

Myers, R.A., Worm, B., 2003. Rapid worldwide depletion of predatory fish communities. Nature 423, 280-283. https://doi.org/10.1038/nature01610.

Nam, D.-H., Adams, D.H., Reyier, E.A., Basu, N., 2011. Mercury and selenium levels in lemon sharks (Negaprion brevirostris) in relation to a harmful red tide event Environ. Monit. Assess. 176, 549-559. https://doi.org/10.1007/s10661-010 1603-4.

Natanson, L.J., Adams, D.H., Winton, M.V., Maurer, J.R., 2014. Age and growth of the bull shark in the western north atlantic ocean. Trans. Am. Fish. Soc. 143, 732-743. https://doi.org/10.1080/00028487.2014.892537.

Perrot, V., Masbou, J.V., Pastukho, v M.N., Epov, V., Point, D., Bérail, S., Becker, R. Sonke, P.E., J, Amouroux, D., 2016. Natural Hg isotopic composition of differen $\mathrm{Hg}$ compounds in mammal tissues as a proxy for in vivo breakdown of toxic methylmercury. Metallomics 8, 170-178. https://doi.org/10.1039/C5MT00286A.

Perrot, V., Pastukhov, M.V., Epov, V.N., Husted, S., Donard, O.F.X., Amouroux, D., 2012. Higher mass-independent isotope fractionation of methylmercury in the pelagic food web of lake baikal (Russia). Environ. Sci. Technol. 46, 5902-5911. https://doi.org/10.1021/es204572g.

Pethybridge, H., Choy, C.A., Logan, J.M., Allain, V., Lorrain, A., Bodin, N., Somes, C.J., Young, J., Ménard, F., Langlais, C., Duffy, L., Hobday, A.J., Kuhnert, P., Fry, B., Menkes, C., Olson, R.J., 2018. A global meta-analysis of marine predator nitrogen stable isotopes: relationships between trophic structure and environmental conditions. Global Ecol. Biogeogr. 27, 1043-1055. https://doi.org/10.1111 geb.12763.

Pethybridge, H., Cossa, D., Butler, E.C.V., 2010. Mercury in 16 demersal sharks from southeast Australia: biotic and abiotic sources of variation and consumer health implications. Mar. Environ. Res. 69, 18-26. https://doi.org/10.1016/ marenvres.2009.07.006.

$\mathrm{R}$ Core Team, 2019. R: A language and environment for statistical computing.
R Foundation for Statistical Computing, Vienna, Austria. https://www.R-project. org

Roff, G., Brown, C.J., Priest, M.A., Mumby, P.J., 2018. Decline of coastal apex shark populations over the past half century. Commun. Biol. 1, 223. https://doi.org/ 10.1038/s42003-018-0233-1.

Roff, G., Doropoulos, C., Rogers, A., Bozec, Y.-M., Krueck, N.C., Aurellado, E., Priest, M., Birrell, C., Mumby, P.J., 2016. The ecological role of sharks on coral reefs. Trends Ecol. Evol. 31, 395-407. https://doi.org/10.1016/j.tree.2016.02.014.

Ruiz-de-Cenzano, M., Rochina-Marco, A., Cervera, M.L., de la Guardia, M., 2014 Speciation of methylmercury in market seafood by thermal degradation, amalgamation and atomic absorption spectroscopy. Ecotoxicol. Environ. Saf. 107, 90-96. https://doi.org/10.1016/j.ecoenv.2014.05.015.

Sackett, D.K., Drazen, J.C., Choy, C.A., Popp, B., Pitz, G.L., 2015. Mercury sources and trophic ecology for Hawaiian bottomfish. Environ. Sci. Technol. 49, 6909-6918. https://doi.org/10.1021/acs.est.5b01009.

Sackett, D.K., Drazen, J.C., Popp, B.N., Choy, C.A., Blum, J.D., Johnson, M.W., 2017. Carbon, nitrogen, and mercury isotope evidence for the biogeochemical history of mercury in Hawaiian marine bottomfish. Environ. Sci. Technol. 51, 13976-13984. https://doi.org/10.1021/acs.est.7b04893.

Sardenne, F., Hollanda, S., Lawrence, S., Albert-Arrisol, R., Degroote, M., Bodin, N., 2017. Trophic structures in tropical marine ecosystems: a comparative investigation using three different ecological tracers. Ecol. Indicat. 81, 315-324. https://doi.org/10.1016/j.ecolind.2017.06.001.

Scheuhammer, A., Braune, B., Chan, H.M., Frouin, H., Krey, A., Letcher, R., Loseto, L. Noël, M., Ostertag, S., Ross, P., Wayland, M., 2015. Recent progress on our understanding of the biological effects of mercury in fish and wildlife in the Canadian Arctic. Sci. Environ. Special Issue: Mercury in Canada's North 509-510, 91-103. https://doi.org/10.1016/j.scitotenv.2014.05.142.

Senn, D.B., Chesney, E.J., Blum, J.D., Bank, M.S., Maage, A., Shine, J.P., 2010. Stable isotope $(\mathrm{N}, \mathrm{C}, \mathrm{Hg}$ ) study of methylmercury sources and trophic transfer in the northern gulf of Mexico. Environ. Sci. Technol. 44, 1630-1637. https://doi.org/ $10.1021 /$ es902361j.

Trystram, C., 2016. Écologie trophique de poissons prédateurs et contribution à l'étude des réseaux trophiques marins aux abords de La Réunion.

Trystram, C., Rogers, K.M., Soria, M.M., Jaquemet, S., 2016. Feeding patterns of two sympatric shark predators in coastal ecosystems of an oceanic island. Can. J. Fish. Aquat. Sci. https://doi.org/10.1139/cjfas-2016-0105.

Trystram, C., Roos, D., Guyomard, D., Jaquemet, S., 2015. Mechanisms of trophic partitioning within two fish communities associated with a tropical oceanic island. West. Indian Ocean J. Mar. Sci. 14, 93-111.

Tsui, M.T.-K., Blum, J.D., Kwon, S.Y., 2020. Review of stable mercury isotopes in ecology and biogeochemistry. Sci. Total Environ. 716, 135386. https://doi.org/ 10.1016/j.scitotenv.2019.135386.

Wang, X., Wu, F., Wang, W.-X., 2017. In vivo mercury demethylation in a marine fish (Acanthopagrus schlegeli). Environ. Sci. Technol. 51, 6441-6451. https://doi.org/ 10.1021/acs.est.7b00923.

Werry, J.M., Lee, S.Y., Lemckert, C.J., Otway, N.M., 2012. Natural or artificial? Habitatuse by the bull shark, Carcharhinus leucas. PloS One 7, e49796. https://doi.org/ 10.1371/journal.pone.0049796.

Werry, J.M., Lee, S.Y., Otway, N.M., Hu, Y., Sumpton, W., 2011. A multi-faceted approach for quantifying the estuarine-nearshore transition in the life cycle of the bull shark, Carcharhinus leucas. Mar. Freshw. Res. 62, 1421-1431. https:// doi.org/10.1071/MF11136.

Werry, J.M., Planes, S., Berumen, M.L., Lee, K.A., Braun, C.D., Clua, E., 2014. Reef-fidelity and migration of tiger sharks, Galeocerdo cuvier, across the coral sea. PloS One 9, e83249. https://doi.org/10.1371/journal.pone.0083249.

Zhang, Y., Jaeglé, L., Thompson, L., 2014. Natural biogeochemical cycle of mercury in a global three-dimensional ocean tracer model. Global Biogeochem. Cycles 28, 553-570. https://doi.org/10.1002/2014GB004814.

Zheng, W., Foucher, D., Hintelmann, H., 2007. Mercury isotope fractionation during volatilization of $\mathrm{Hg}(0)$ from solution into the gas phase. J. Anal. Atomic Spectrom. 22, 1097-1104. https://doi.org/10.1039/B705677J. 